\title{
Cycloaddition reactions of porphyrins
}

\author{
José A. S. Cavaleiro, ${ }^{*}$ Maria G. P. M. S. Neves, and Augusto C. Tomé \\ Department of Chemistry, University of Aveiro, 3810-193 Aveiro, Portugal \\ E-mail: jcavaleiro@dq.ua.pt
}

\section{Dedicated to Professor Branko Stanovnik, University of Ljubljana, Slovenia, on the occasion of his $65^{\text {th }}$ birthday}

(received 27 Aug 03; accepted 12 Oct 03; published on the web 17 Oct 03)

\begin{abstract}
Adequately substituted porphyrins can participate in pericyclic reactions as dienes, dienophiles, dipolarophiles and as 1,3-dipoles. They also show interesting dipolar 1,5-electrocyclizations and cheletropic reactions with carbenes. All these different types of reactivity have been exploited in order to synthesize new potential biologically active porphyrin derivatives, mainly chlorins and bacteriochlorins. This paper reviews the most recent works where porphyrins have participated in pericyclic reactions.
\end{abstract}

Keywords: Porphyrins, chlorins, bacteriochlorins, isobacteriochlorins, naphthoporphyrins, pyrroloporphyrins, Diels-Alder reaction, 1,3-dipolar cycloaddition, 1,5-electrocyclization, carbenes, nitrenes

\section{Contents}

Introduction

1. Porphyrins as Dienes

2. Porphyrins as Dienophiles

3. Porphyrins as Dipolarophiles

4. Porphyrins as 1,3-Dipoles

5. Electrocyclizations

6. Cheletropic Reactions

Acknowledgements

References

\section{Introduction}


Amongst natural heterocycles the porphyrin-type compounds have a prominent position in Nature. It is known for a long time that certain vital functions, like respiration, photosynthesis, drug detoxification, and others depend on the action of some porphyrin-type metal complexes. Life without such compounds would be totally different from what it is on Earth. It was early recognised $^{1}$ that there is a close relationship between protoheme, the respiratory enzymes' prosthetic group, and chlorophyll $a$, a photosynthetic green pigment in plants. A great deal of work has been put since then on the establishment of synthetic routes leading to porphyrin derivatives. Two landmarks have to be mentioned: the synthesis of protoporphyrin-IX (1) by Fischer in $1929,{ }^{2}$ and the synthesis of chlorophyll $a$ (2) by Woodward and his seventeen postdoctoral colleagues in $1960 .^{3}$ Research has also been centred on physical chemistry and biochemical aspects of such macrocycles. ${ }^{4,5}$ More recently several groups have reported promising applications for porphyrin derivatives. Mimicking the cytochrome $\mathrm{P}_{450}$ activity, several metalloporphyrins can be used as oxidative catalysts. ${ }^{6}$ On the biological side it is known that such compounds can be used in the diagnosis and treatment of neoplastic diseases. ${ }^{7}$ Certain types of cancer are being treated in several countries by using a formulation containing a purified derivative of hematoporphyrin $\left(\right.$ Photofrin $^{\circledR}$ ), the technique being known as Photodynamic Therapy (PDT). Bactericidal and virucidal activities are also known for some porphyrins. ${ }^{8}$ More recently, the age-related macular degeneration is being treated by, using a chlorin (a dihydrotype porphyrin) derivative (3). ${ }^{7}$ Other derivatives, such as bacteriochlorins (tetrahydro-type porphyrins) are being tested in PDT. Due to their intense absorption in the red region of the spectrum, chlorins and bacteriochlorins might play a key role against cancer and other diseases. How can such types of porphyrin derivatives be made? Certainly by total chemical synthesis. However many steps may be involved with the synthesis of several intermediates. A better alternative can be the chemical modification of simple porphyrins, namely via cycloaddition transformations. For instance, if a porphyrin macrocycle is substituted with a vinyl group, then the latter and a peripheral double bond of the macrocycle can act as a diene system. In such way the macrocycle can react with dienophiles to yield Diels-Alder adducts. Our group has shown that meso-tetraarylsubstitued porphyrins can also participate as dienophiles or as dipolarophiles, increasing the possibilities of using these compounds in other types of cycloadditions. New derivatives of the porphyrin, chlorin and bacteriochlorin types have been obtained in good yields using such types of transformations. 

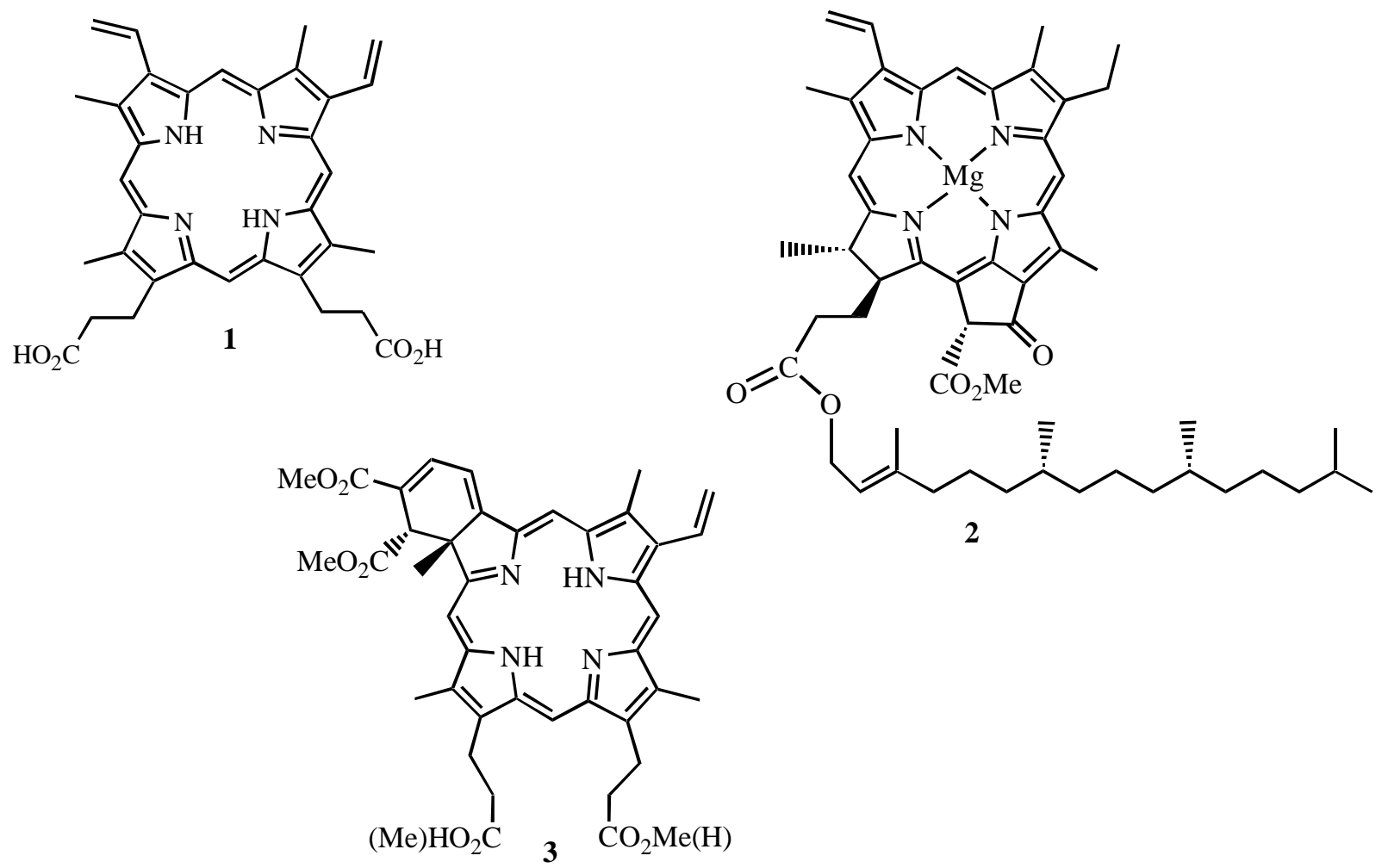

\section{Porphyrins as Dienes}

It was recognized more than thirty years ago that vinyl porphyrins can react as dienes ${ }^{9,10}$ and since then this has been the subject of several studies. In 1969 the formation of photoproducts such as $\mathbf{6}$, obtained in the reaction of protoporphyrin-IX dimethyl ester $\mathbf{4}$ with singlet oxygen, was explained via the intermediate [4+2] adduct 5 (Scheme 1). ${ }^{9}$ The cycloaddition was referred to occur in either pyrrolic unit but not in both.

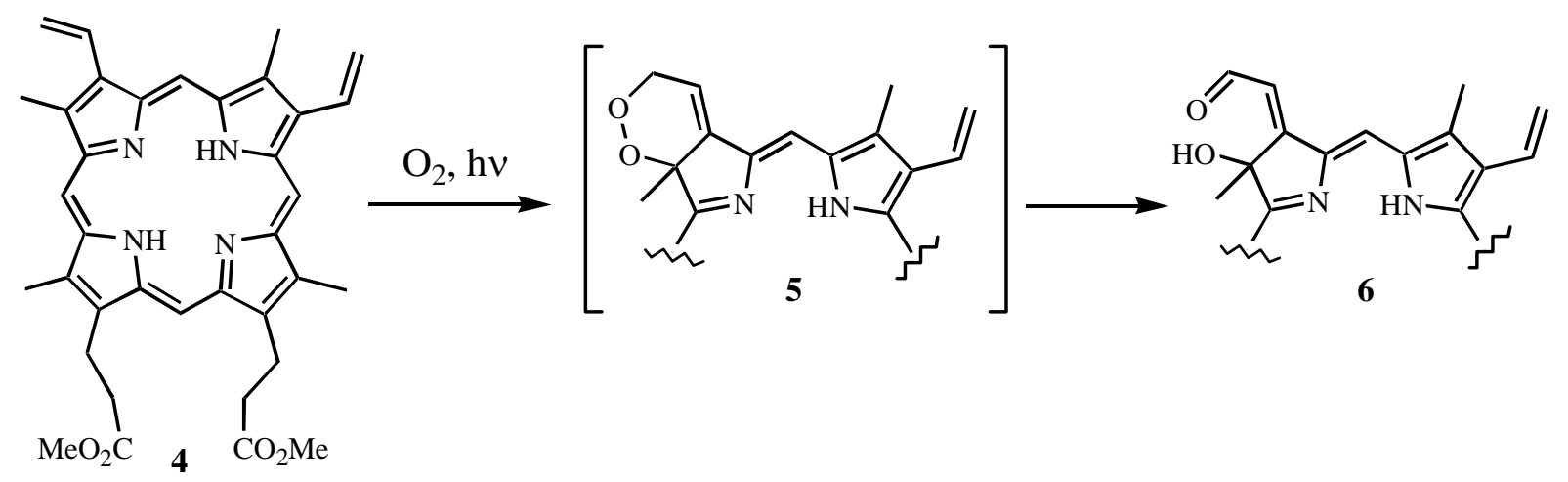

\section{Scheme 1}

During the same period, the reactivity of protoporphyrin-IX dimethyl ester with tetracyanoethylene (TCNE) and dimethyl acetylenedicarboxylate (DMAD) was reported to 
afford isobacteriochlorins (bis-adducts). ${ }^{10}$ Subsequent reinvestigation of the reaction of protoporphyrin-IX di(t-butyl) ester with TCNE has reported a more complex situation. ${ }^{11}$ Monoadducts (7-9) and bis-adducts (10-13) from [2+2] and [4+2] cycloadditions were obtained; the expected isobacteriochlorin $\mathbf{1 3}$ was only isolated in minor amount.
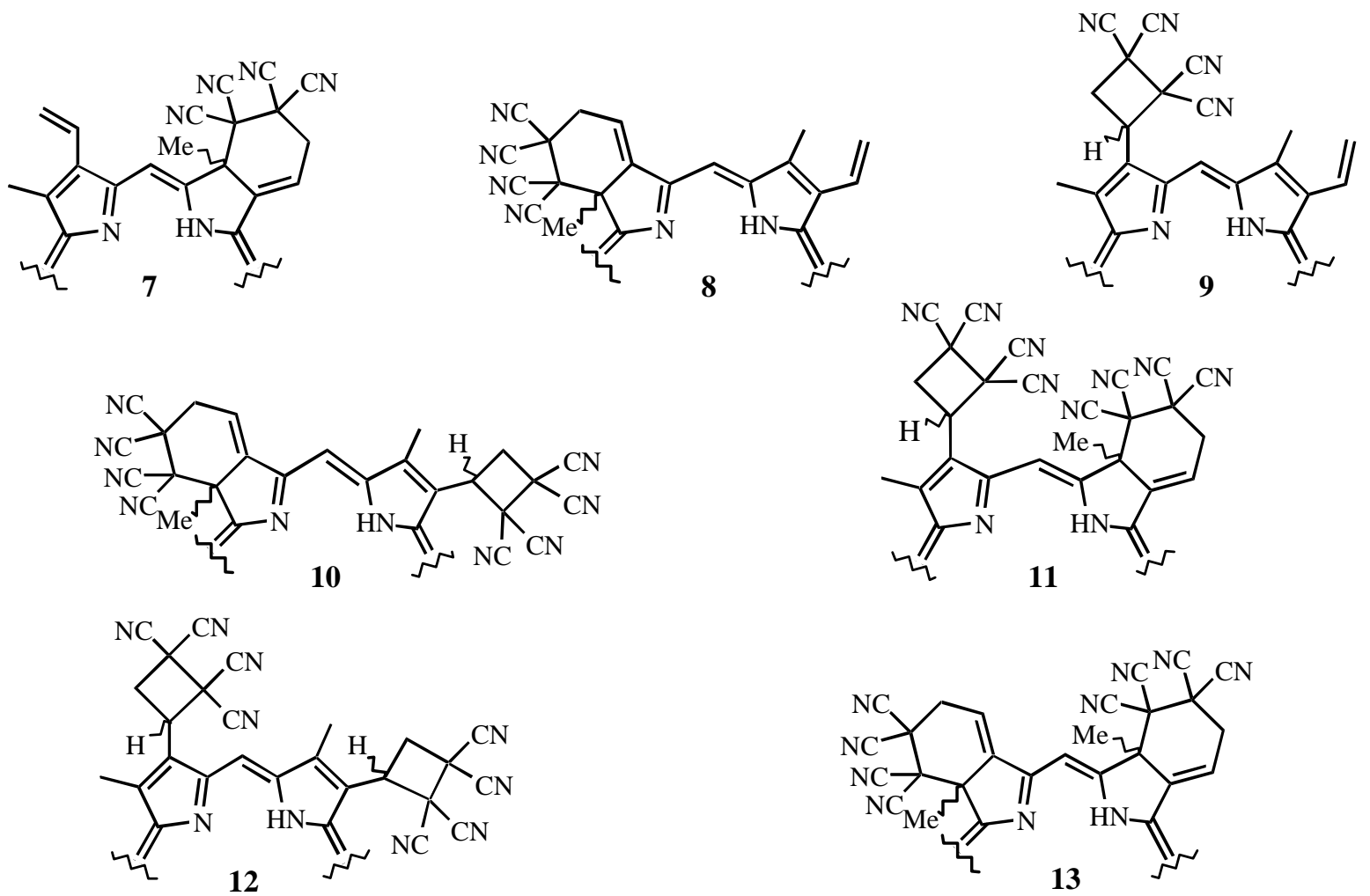

The reaction of protoporphyrin-IX with DMAD was also revised. ${ }^{12}$ Only monoadducts were obtained (e.g. 14); the elimination of the angular methyl group was described to afford monobenzoporphyrins 15. A direct access to benzoporphyrins was also reported by the same group using a Diels-Alder reaction of a $\beta$-unsubstituted- $\beta$-vinylporphyrin with an excess of DMAD. $^{13}$ The reaction of protoporphyrin-IX with other dienophiles (e.g. $\beta$-phenylsulphonylpropiolate, $\beta$-phenylsulphonylacrylonitrile) has also been reported. ${ }^{12}$
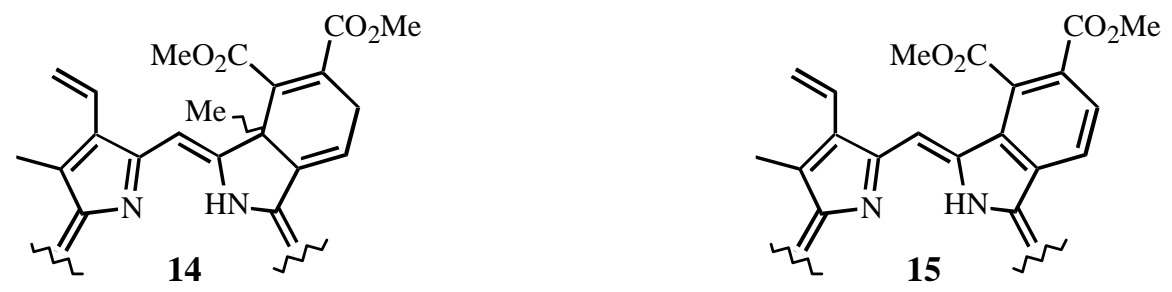

The possibility of $\beta$-vinyl-meso-tetraarylporphyrins $\mathbf{1 6}$ to act as dienes in Diels-Alder reaction was also investigated. ${ }^{14}$ With TCNE both the [4+2] and [2+2] adducts, respectively 17 
and 18, are obtained (Scheme 2). NMR studies showed that the [2+2] adduct can be obtained by rearrangement of the [4+2] chlorin.

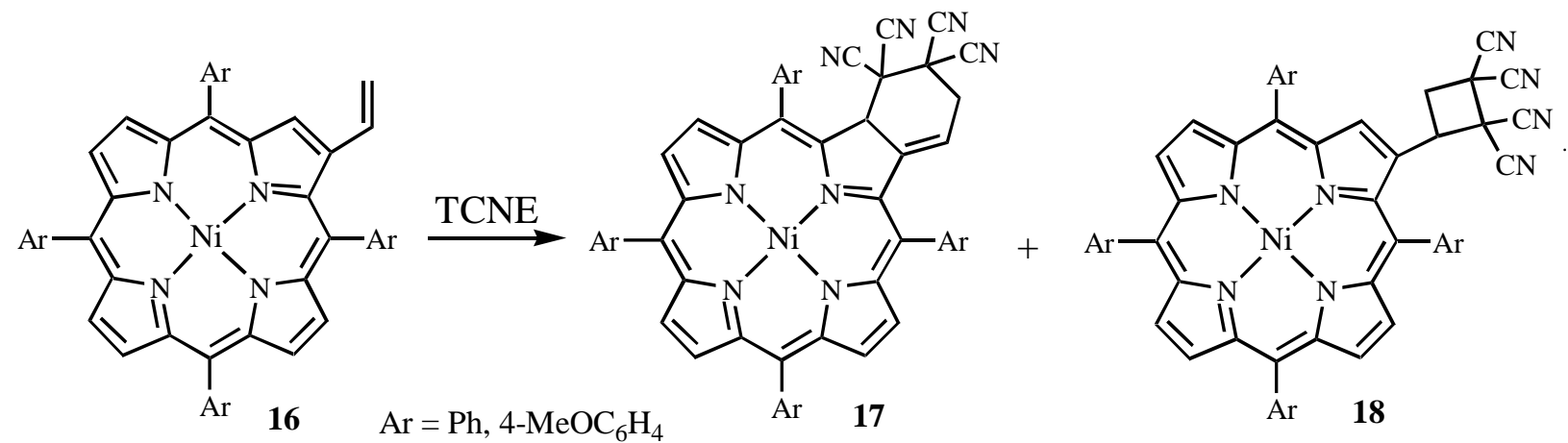

\section{Scheme 2}

The vinylporphyrin $16(\mathrm{Ar}=\mathrm{Ph})$ also reacts with DMAD to yield chlorin 19 and the benzoporphyrin 20. ${ }^{15}$ Compound 20 can be obtained in quantitative yield by oxidation of 19 with DDQ. Later, the reaction of $\mathbf{1 6}$ with DMAD and with other dienophiles was reinvestigated but the results are identical to those already published. ${ }^{16}$ These reactions give different yields when carried out at normal or at high pressure.
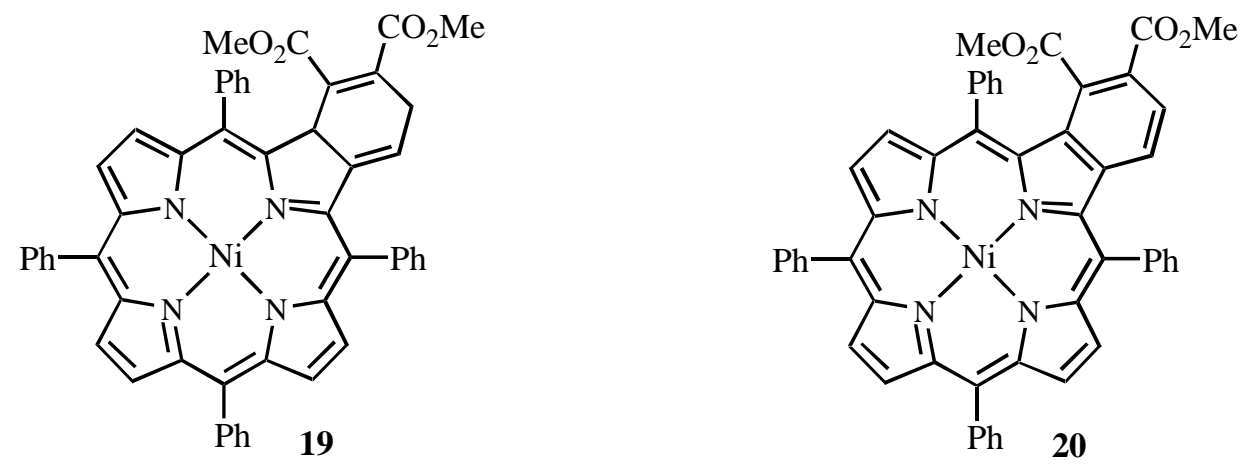

The same type of approach was also used to synthesize new chlorins, bacteriochlorins and benzoporphyrins from protoporphyrin-IX or other divinylporphyrins, chlorophylls and analogues, in order to evaluate their potential applications in PDT. ${ }^{17}$ Treatment of bromovinylheptaethylporphyrin 21 with TCNE gives the novel chlorins 22 and 23 presumably via the initially formed Diels-Alder adduct (Scheme 3). ${ }^{18}$ 


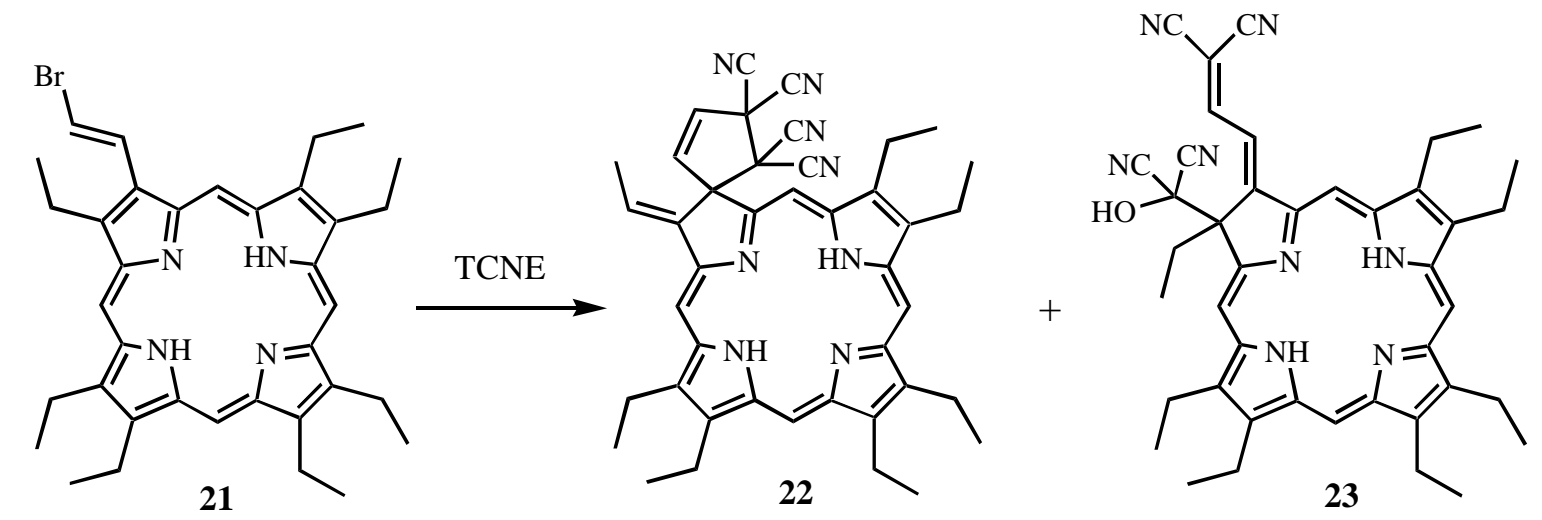

\section{Scheme 3}

The reaction of porphyrins with heterodienophiles was also explored. For instance, protoporphyrin-IX dimethyl ester reacts with substituted nitrosobenzenes to yield the Diels-Alder adducts. ${ }^{19}$ However, even with the more reactive ones (with electron-withdrawing substituents) only the monoadducts 24a and 25a are obtained. In the presence of an excess of the dienophile the formyl-monoadducts $\mathbf{2 4 b}$ and $\mathbf{2 5 b}$ are also obtained.

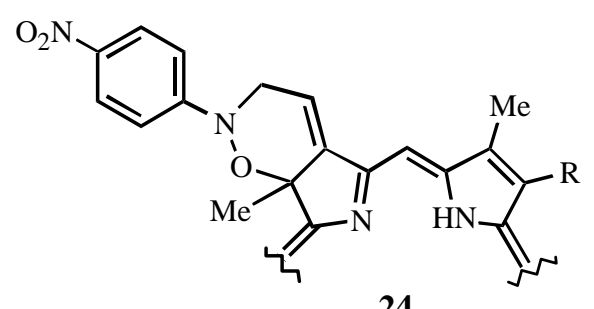

24 a) $\mathrm{R}=\mathrm{CH}=\mathrm{CH}_{2}$

b) $\mathrm{R}=\mathrm{CHO}$

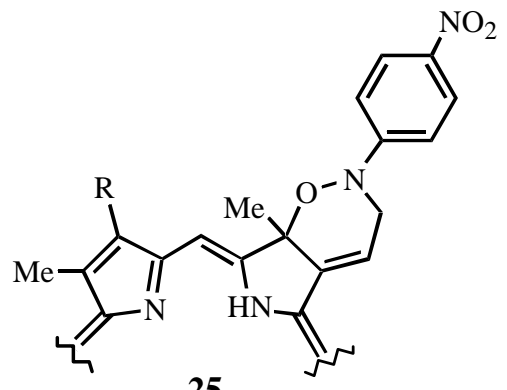

25

The failure to form the desired bis-adduct from protoporphyrin-IX dimethyl ester and the nitrosobenzenes prompted the use of the symmetric protoporphyrin-II dimethyl ester $\mathbf{2 6}$. In this case the bis-adducts $\mathbf{2 8}$ (a mixture of diastereoisomers) were formed and could be identified by visible spectroscopy, NMR, and MS (Scheme 4). ${ }^{19}$ These bacteriochlorins are too unstable to be separated by chromatography and give rise to the formyl-monoadduct 29. 


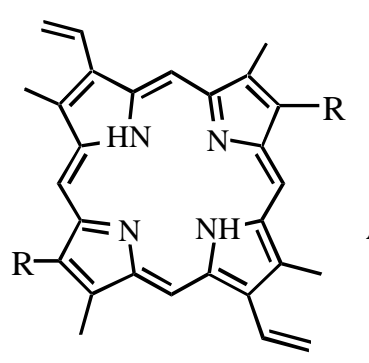

$\mathrm{R}=\mathrm{CH}_{2} \mathrm{CH}_{2} \mathrm{CO}_{2} \mathrm{Me}$

26
$\underset{\mathrm{Ar}=4-\mathrm{NO}_{2} \mathrm{C}_{6} \mathrm{H}_{4}}{\stackrel{\mathrm{ArNO}}{\longrightarrow}}$

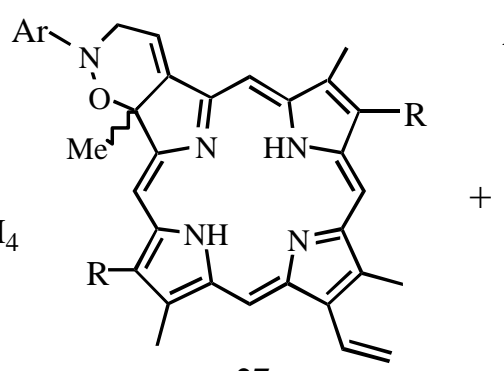

27

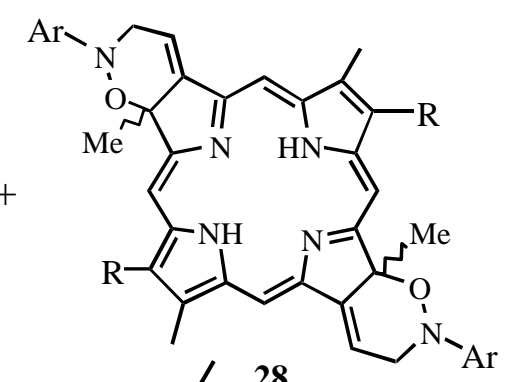

28

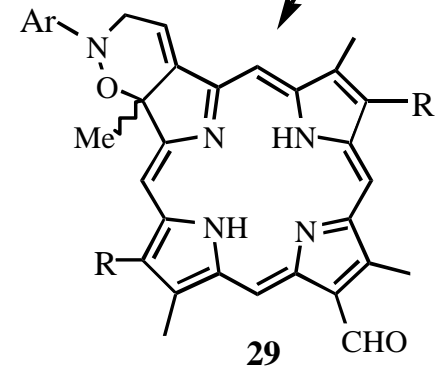

\section{Scheme 4}

The reaction of protoporphyrin-IX dimethyl ester with azo dienophiles, namely 1,2,4triazoline-3,5-dione and $N$-substituted 1,2,4-triazoline-3,5-diones, pyridazine-3,6-dione and ditert-butyl azodicarboxylate was also reported. ${ }^{20}$ With the 1,2,4-triazoline-3,5-diones the [4+2] mono-adducts are obtained and, in most cases, the [4+2]/[2+2] bis-adducts are also identified (Scheme 5). The reaction with pyridazine-3,6-dione gives numerous products which are difficult to separate and with di-tert-butyl azodicarboxylate the reaction does not occur.
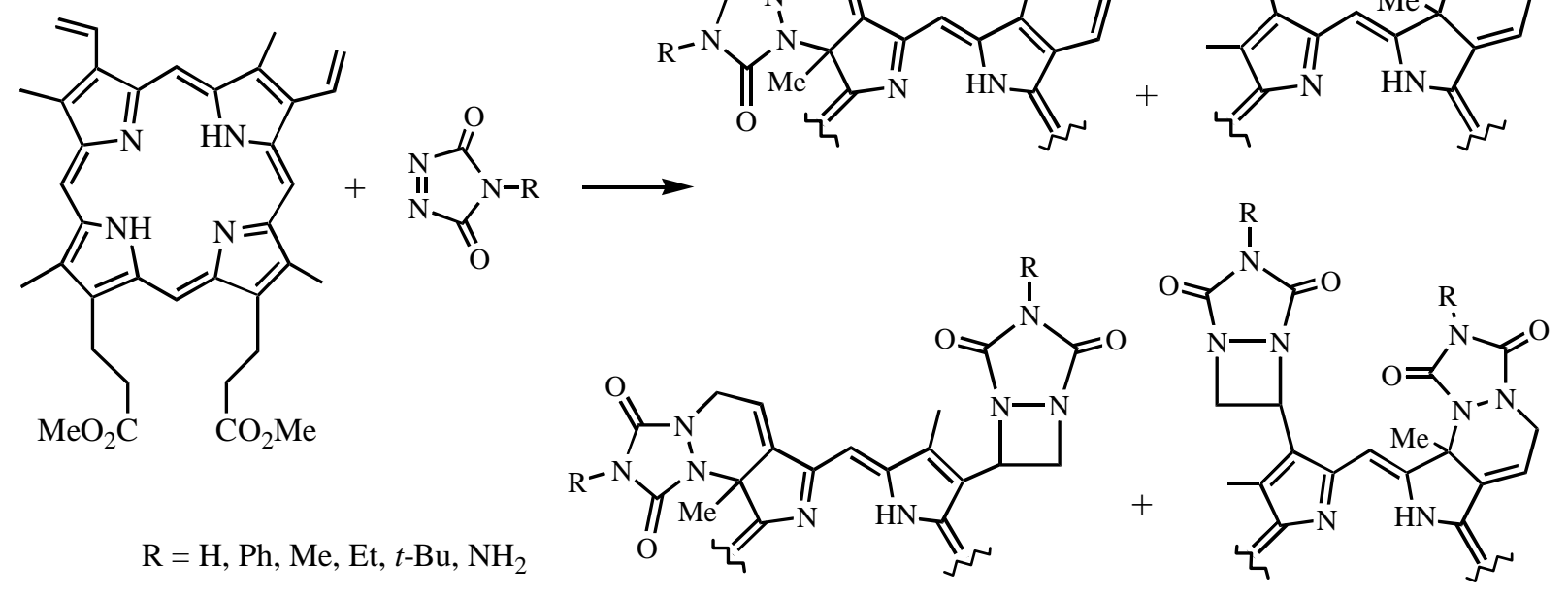

Scheme 5 
The reactivity of $\beta$-imino derivatives of meso-tetraphenylporphyrin $\mathbf{3 0}$ as heterodienes was recently investigated. For instance, in the presence of $\mathrm{La}(\mathrm{OTf})_{3}$ it reacts with 3,4-dihydro- $2 \mathrm{H}$ pyran to afford tetrahydropyridine-fused porphyrins $\mathbf{3 1}$ and pyridoporphyrins $\mathbf{3 2}$ (Scheme 6). ${ }^{21}$

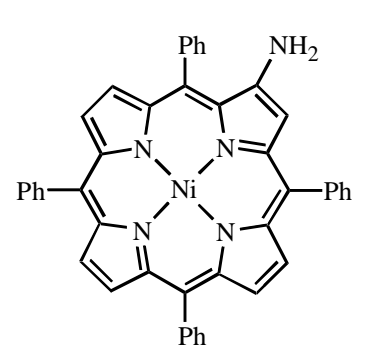<smiles>[R]Cc1ccc(C=O)cc1</smiles><smiles></smiles>

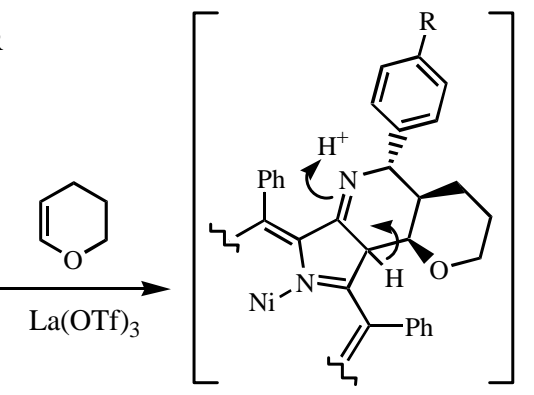

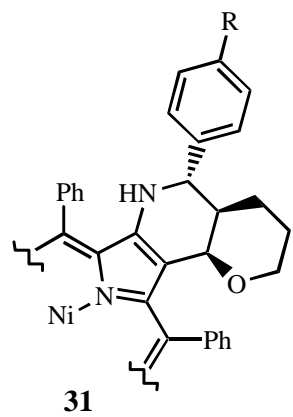

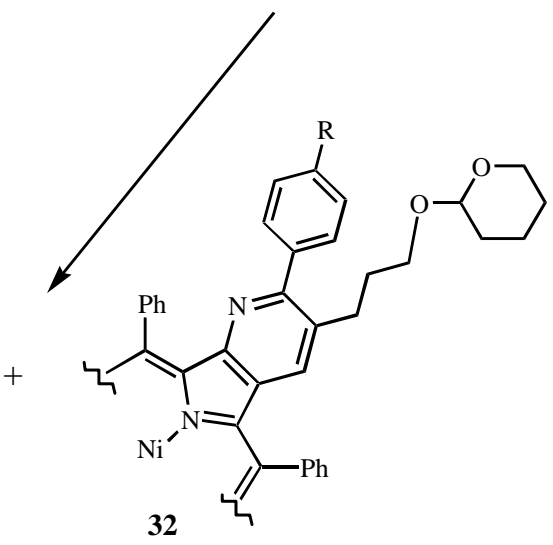

\section{Scheme 6}

Porphyrin ortho-quinodimethanes can be generated by mild thermal extrusion of $\mathrm{SO}_{2}$ from porphyrin-fused 3-sulfolenes and trapped with a range of dienophiles. ${ }^{22}$ As an example, when 33 is heated in the presence of dienophiles the Diels-Alder adducts $\mathbf{3 5}$ and $\mathbf{3 6}$ are obtained (Scheme 7). ${ }^{23}$ 

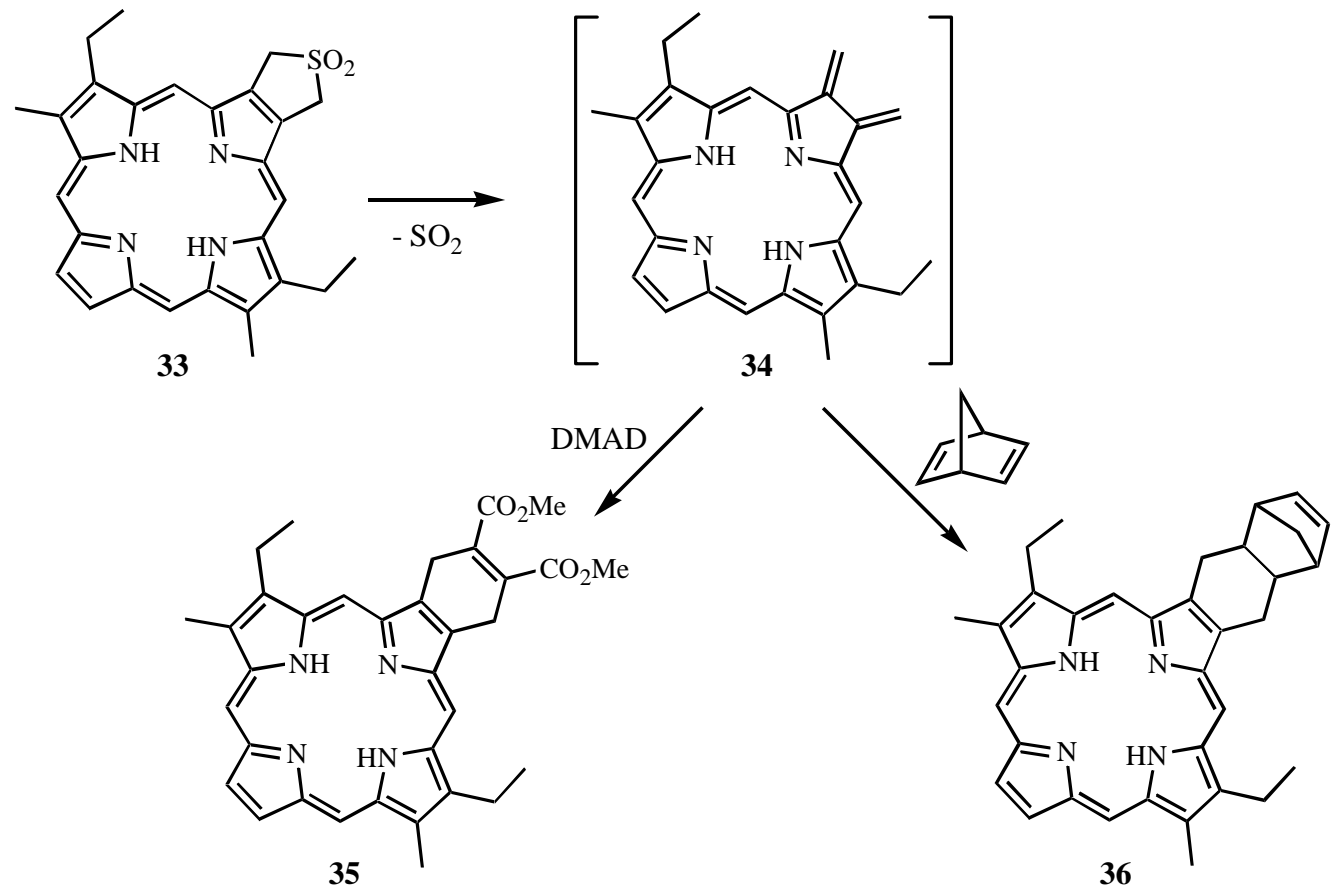

\section{Scheme 7}

Pyrrolo[3,4-b]porphyrins $\quad \mathbf{3 7}^{24}$ and $\quad \mathbf{3 9}^{25}$ give Diels-Alder reactions with acetylenedicarboxylates at the exocyclic pyrrole unit (Scheme 8). Upon prolonged heating in refluxing toluene, derivative $\mathbf{4 0}$ is converted into benzoporphyrins. ${ }^{25}$

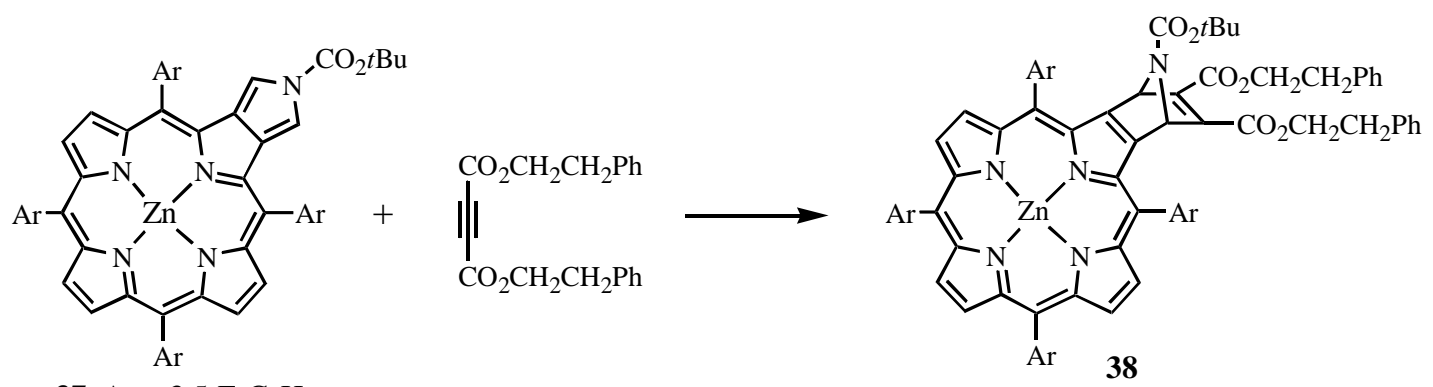

$37, \mathrm{Ar}=3,5-\mathrm{F}_{2} \mathrm{C}_{6} \mathrm{H}_{3}$

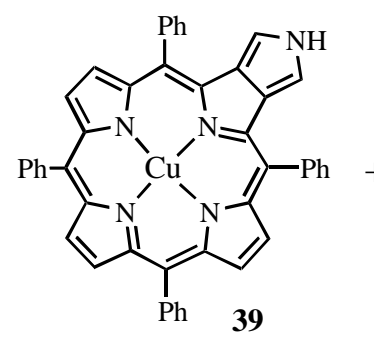<smiles>COC(=O)C#CCCCCCCCCOC(C)=O</smiles>

\section{Scheme 8}


Porphyrins with exocyclic dienic systems have also been used in Diels-Alder reactions with several dienophiles. Compounds $\mathbf{4 1}^{26}$ and $\mathbf{4 4}^{27}$ (Scheme 9) are typical examples. In these cases the $\pi$ electrons of the porphyrin macrocycle are not involved in the reaction.
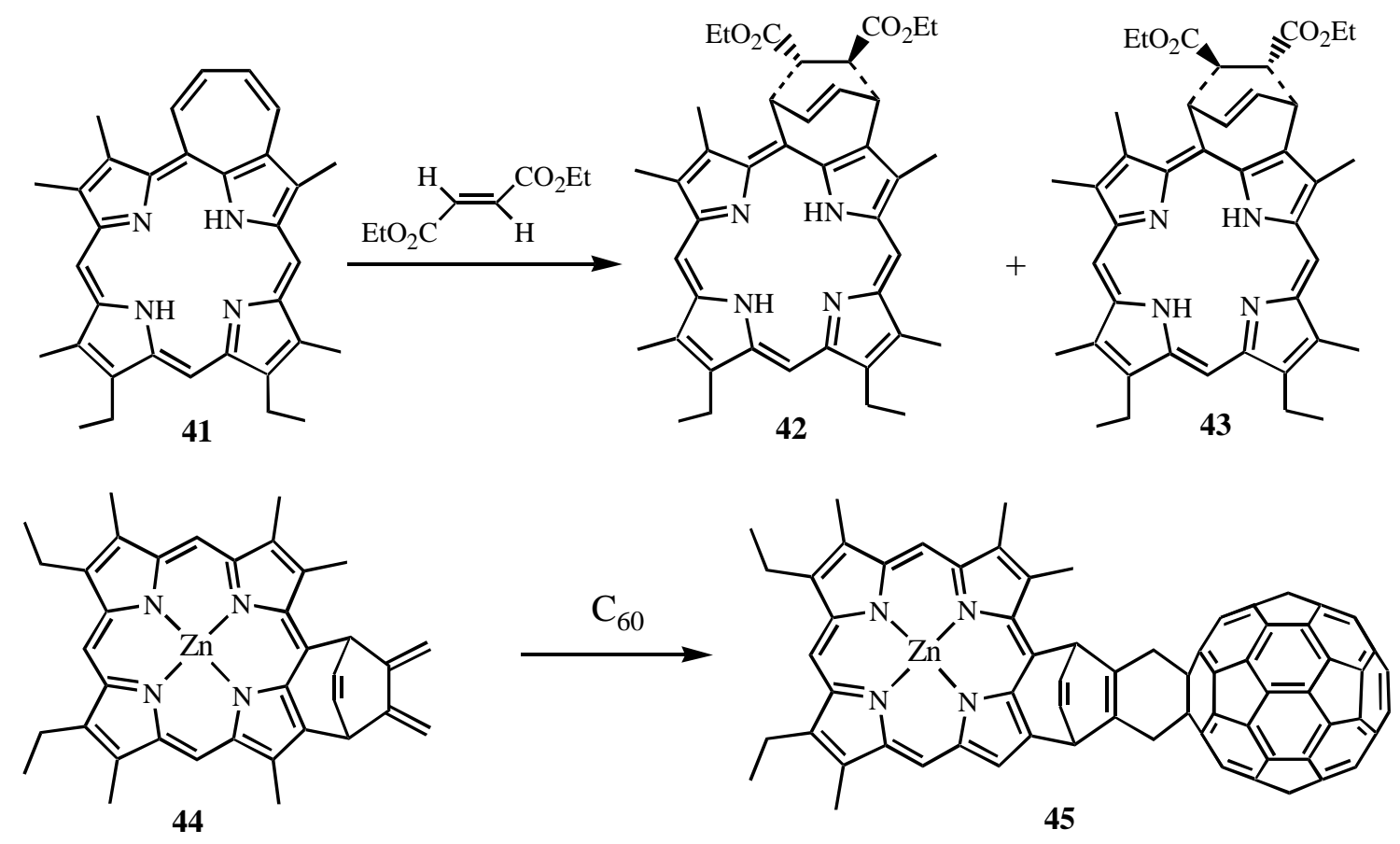

\section{Scheme 9}

Compounds 46, ${ }^{28} \mathbf{4 8},{ }^{29}$ and $50{ }^{30}$ (Scheme 10) are other examples of porphyrinic dienes which have been involved in the synthesis of new porphyrin derivatives, mainly porphyrinfullerene dyads. 


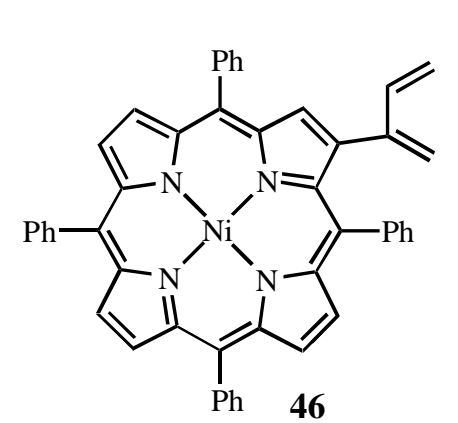

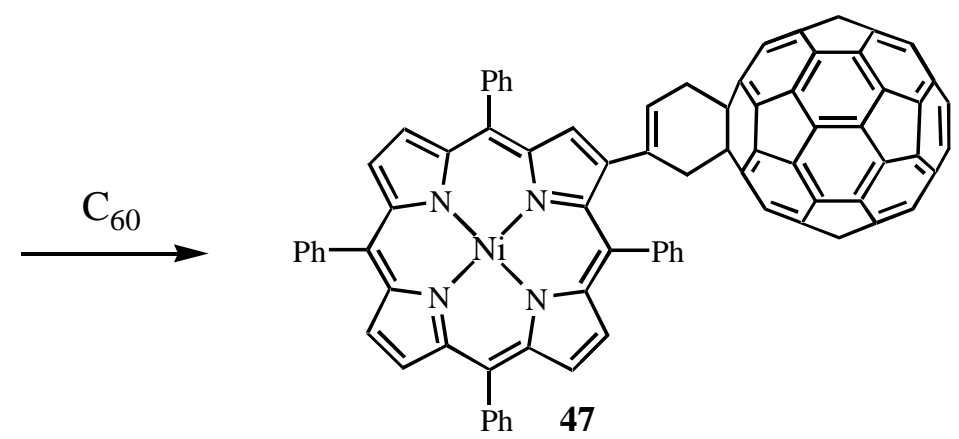

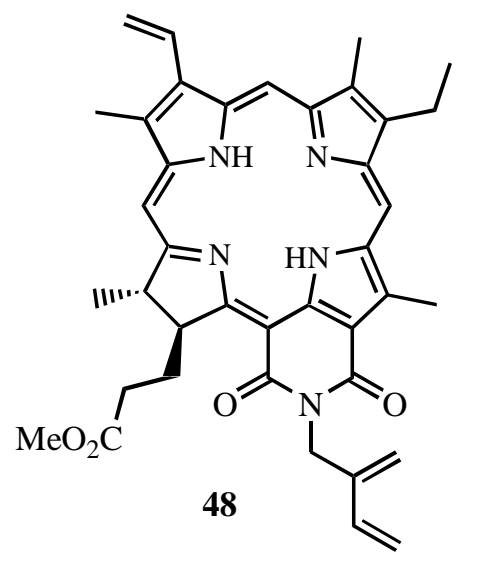

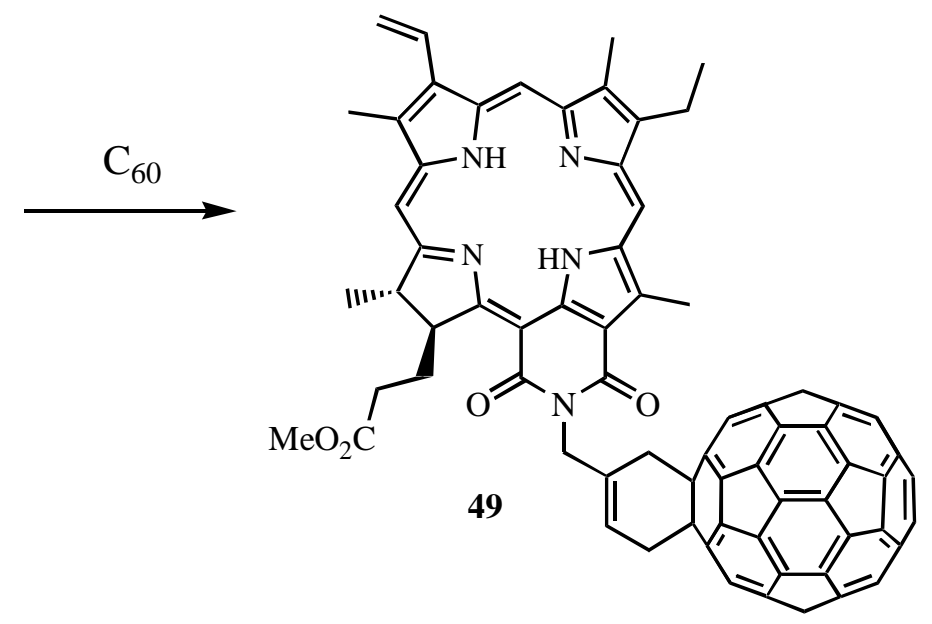

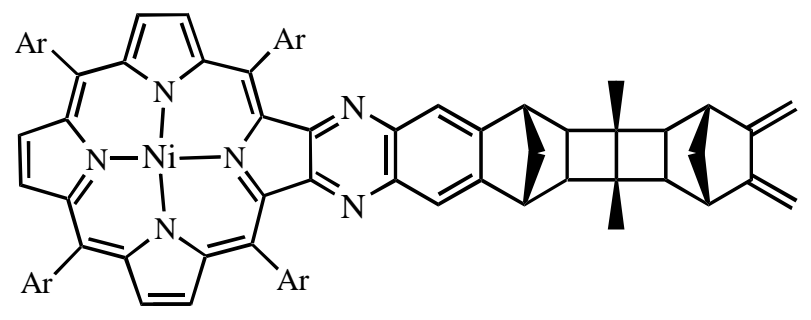

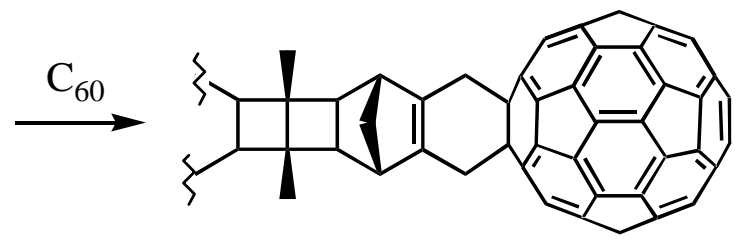

51

50, $\mathrm{Ar}=3,5-(t \mathrm{Bu})_{2} \mathrm{C}_{6} \mathrm{H}_{3}$

\section{Scheme 10}

\section{Porphyrins as Dienophiles}

We have shown for the first time that the peripheric double bonds of the porphyrins can participate in [4+2] cycloadditions, as the $2 \pi$ electrons component. Porphyrins 52a-e react with ortho-benzoquinodimethane 54 (a highly reactive diene generated in situ by, for example, the thermal extrusion of $\mathrm{SO}_{2}$ from sulfone 53) to give chlorins 55 in moderate yields (Scheme 11). ${ }^{31}$ When porphyrins 52a-c are used, together with the expected chlorins 55a-c, two other products are obtained in each case. These are the porphyrins 56 and 57, obtained by dehydrogenation of the corresponding chlorins. 


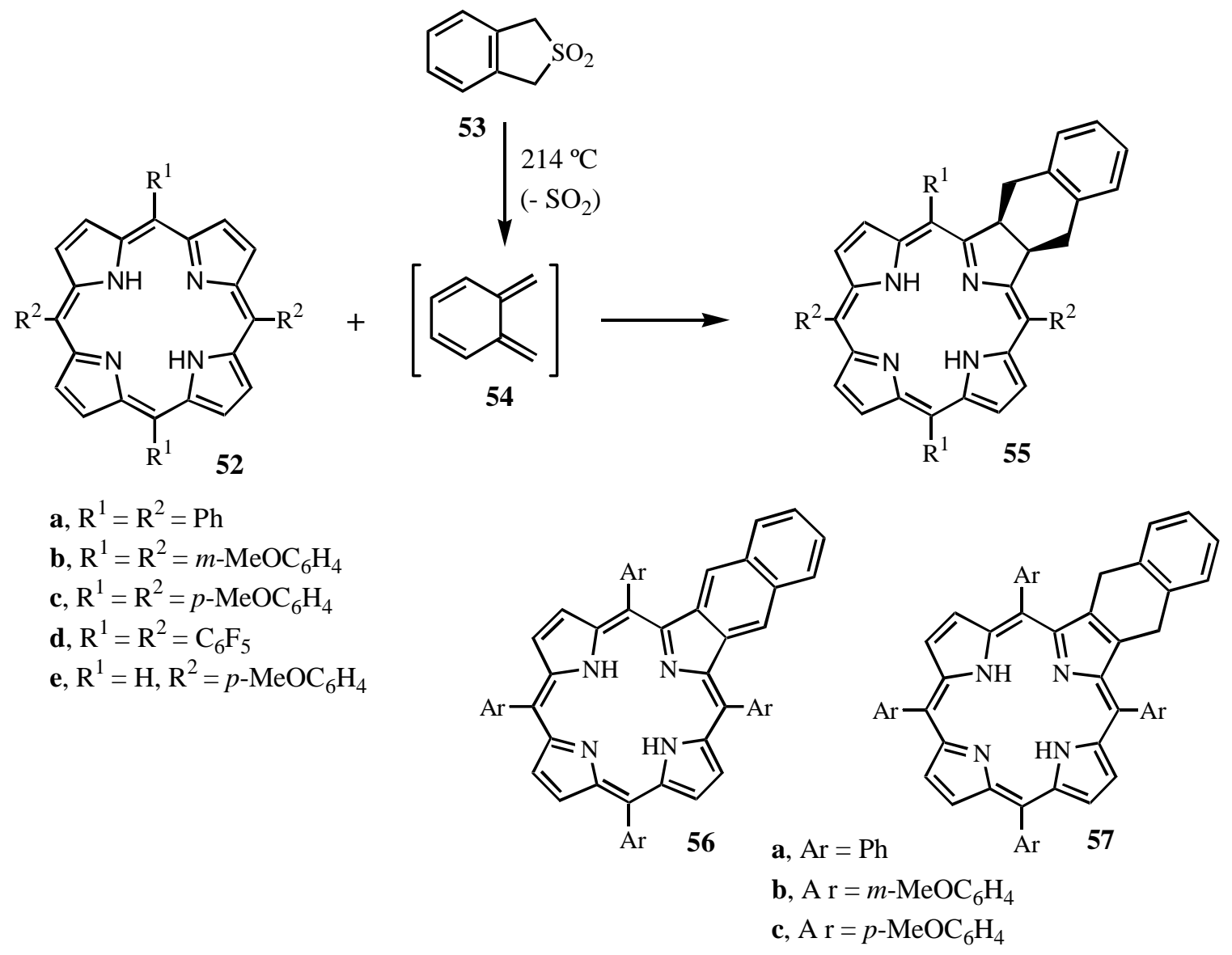

\section{Scheme 11}

However, when meso-tetrakis(pentafluorophenyl)porphyrin 52d is used as dienophile, porphyrins of types 56 and 57 are not formed. The dehydrogenation of the chlorin 55d $\left(\mathrm{Ar}=\mathrm{C}_{6} \mathrm{~F}_{5}\right)$ to $\mathbf{5 6 d}$ and $\mathbf{5 7 d}$ only occurs when it is heated in refluxing toluene in the presence of DDQ. ${ }^{32}$ In the reaction with 52d, together with chlorin 55d, two stereoisomeric bacteriochlorins 58 (cis and trans) are obtained. These bacteriochlorins have very interesting UV-vis absorption properties with strong bands at 747 and $761 \mathrm{~nm}$; this is an important feature to be fulfilled by a good PDT photosensitizer. 


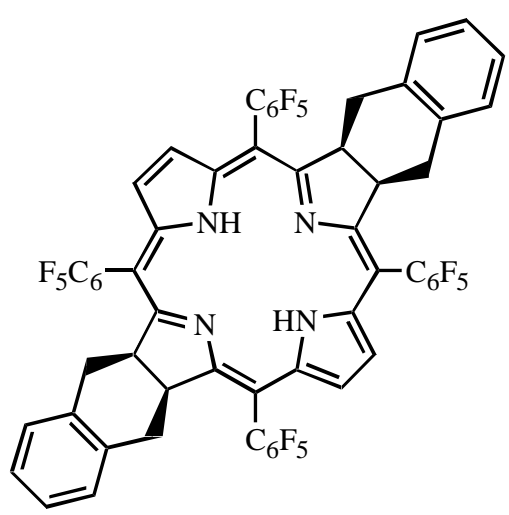

58-cis

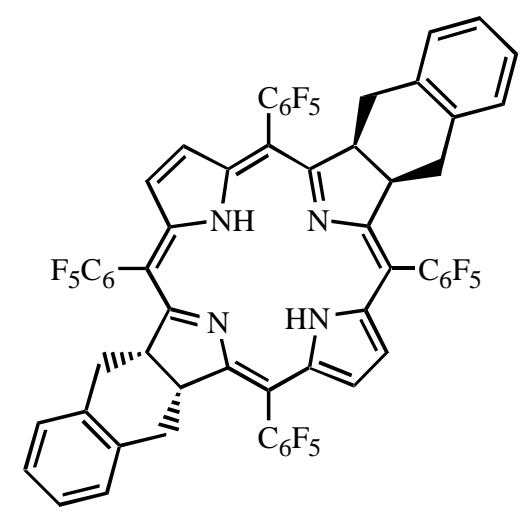

58-trans

The formation of chlorins of type $\mathbf{5 5}$ is also observed when 5,15-disubstituted arylporphyrins are used. For instance, chlorin 55e is the main product from the reaction of 52e with 0 benzoquinodimethane 54 .

Porphyrins also give Diels-Alder reactions with heterocyclic o-quinodimethanes. For instance, the quinazoline-fused chlorin $\mathbf{5 9},{ }^{32}$ the quinoxaline-fused chlorin $\mathbf{6 0},{ }^{33}$ and the isoindole-fused chlorin $\mathbf{6 1}^{34}$ (Scheme 12) are all obtained by this way.
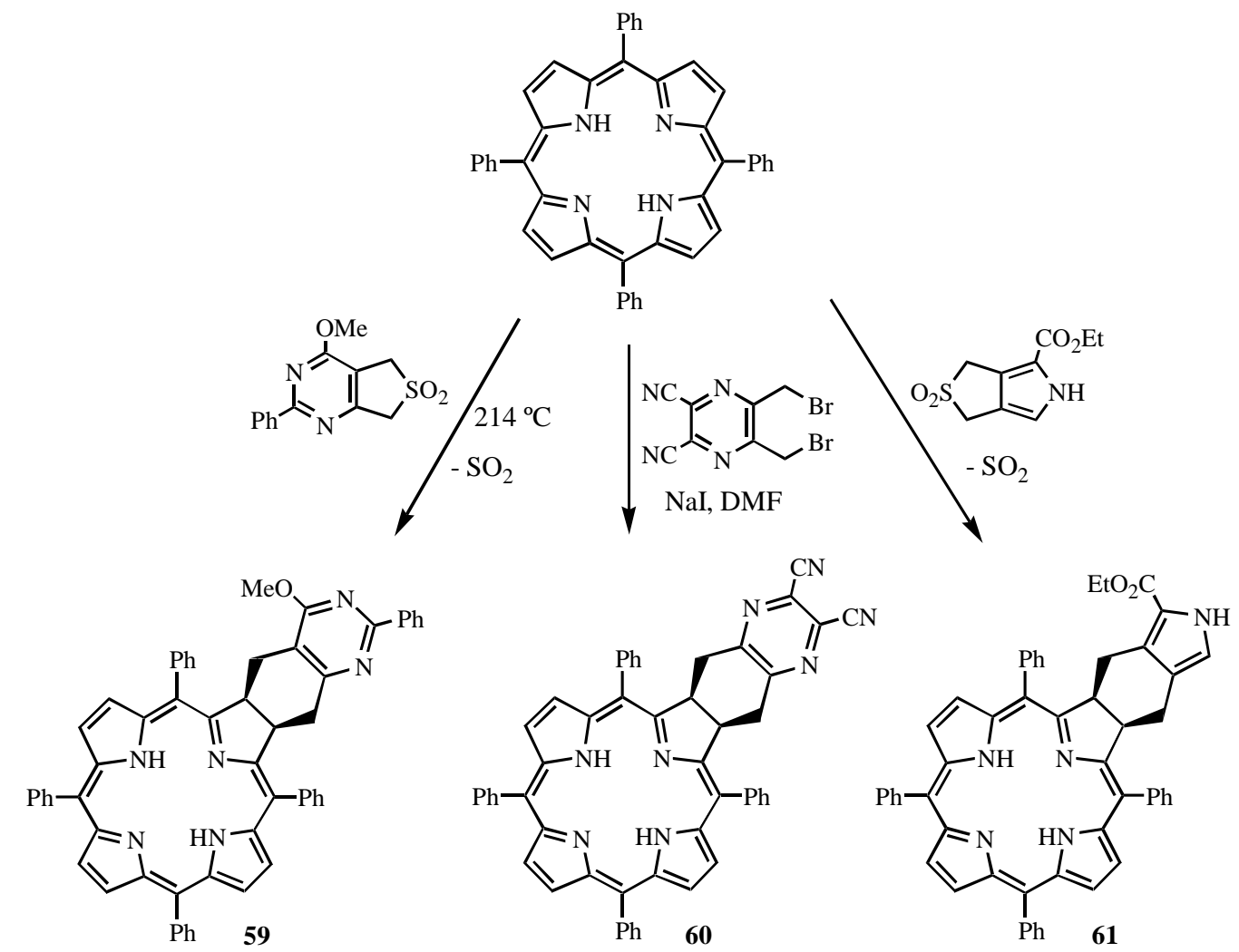

\section{Scheme 12}


Related studies involve the reaction of $o$-benzoquinodimethane with the inverted porphyrin $\mathbf{6 2}$ to give the isoquinolinoporphyrin $\mathbf{6 3}$ (Scheme 13). ${ }^{35}$

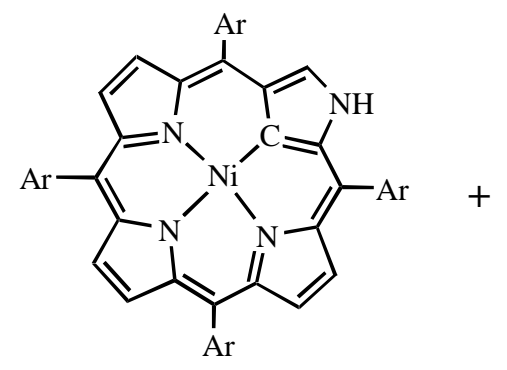

62
a, $\mathrm{Ar}=\mathrm{Ph}$
b, $\mathrm{Ar}=p-\mathrm{MeC}_{6} \mathrm{H}_{4}$

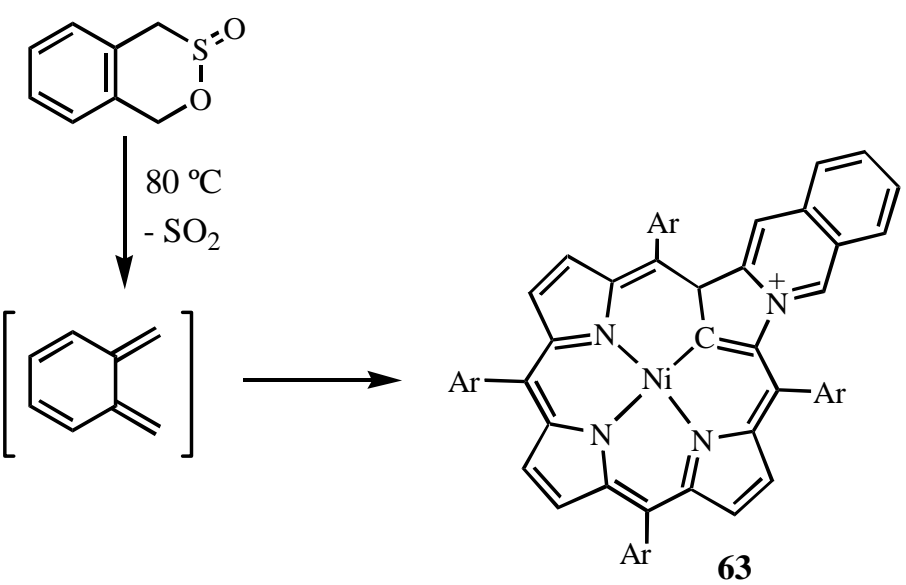

63

\section{Scheme 13}

We have also shown that porphyrins react with "stable" dienes like the commercially available polycyclic hydrocarbon pentacene. When a mixture of this compound and a porphyrin 64 in 1,2,4-trichlorobenzene is heated at $\mathrm{ca} 200^{\circ} \mathrm{C}$, under nitrogen atmosphere, the corresponding Diels-Alder adduct 65 (Scheme 14) is obtained in moderate to good yield (22-87\%). ${ }^{36}$ Using meso-mono- (64a), meso-di- (64b,c) and meso-tetraarylporphyrins (64d-f) as dienophiles a range of novel chlorins with an interesting and unusual three-dimensional structure can be obtained. As expected, with porphyrin 64a two regioisomeric chlorins are obtained. All chlorins 65 show strong absorption bands at ca $650 \mathrm{~nm}$ in their UV-vis spectra.

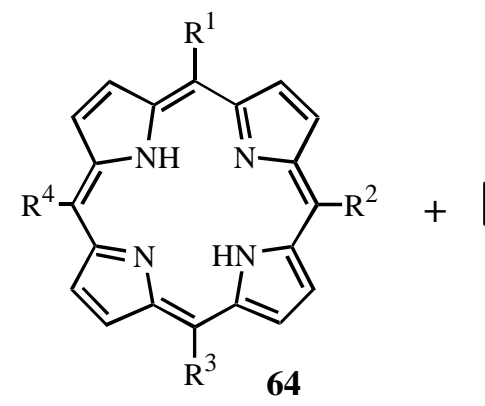
a, $\mathrm{R}^{1}=3-\mathrm{MeOC}_{6} \mathrm{H}_{4}, \mathrm{R}^{2}=\mathrm{R}^{3}=\mathrm{R}^{4}=\mathrm{H}$
b, $\mathrm{R}^{1}=\mathrm{R}^{3}=4-\mathrm{MeOC}_{6} \mathrm{H}_{4}, \mathrm{R}^{2}=\mathrm{R}^{4}=\mathrm{H}$
c, $\mathrm{R}^{1}=\mathrm{R}^{3}=3-\mathrm{MeOC}_{6} \mathrm{H}_{4}, \mathrm{R}^{2}=\mathrm{R}^{4}=\mathrm{H}$

\section{Scheme 14}


A related work involved the reaction of the tetraazaporphyrin $\mathbf{6 6}$ with anthracene and naphthacene to yield the corresponding tetraazachlorins 67 and 68 (Scheme 15). ${ }^{37}$ Bis-adducts of the bacteriochlorin and isobacteriochlorin types are also obtained.

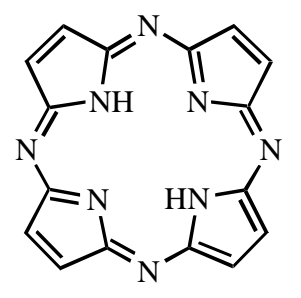

66
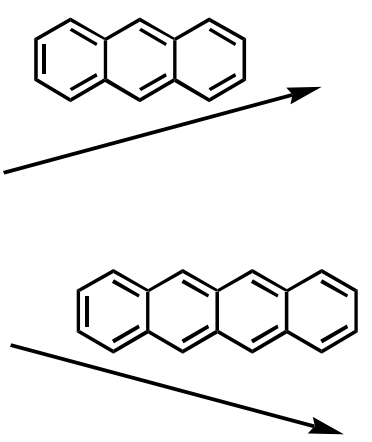

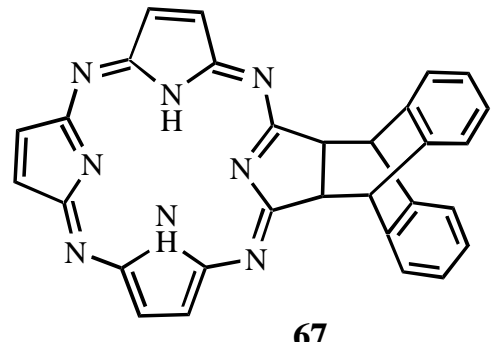

67

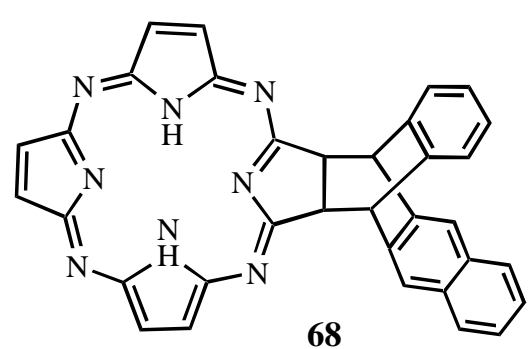

\section{Scheme 15}

\section{Porphyrins as Dipolarophiles}

Porphyrins behave as dipolarophiles in the reaction with a range of 1,3-dipoles, namely azomethine ylides, nitrones, diazoalkanes and carbonyl ylides. Chlorins of type $\mathbf{7 0}$ (Scheme 16) are obtained as the main products when the azomethine ylide $\mathbf{6 9}$ is generated in the presence of porphyrins 52a, 52d and 52f, in refluxing toluene. ${ }^{38}$ In the reaction using porphyrin 52a the corresponding chlorin 70a is the sole product. However, with porphyrins 52d and 52f, together with chlorins 70, isobacteriochlorins $\mathbf{7 1}$ are also obtained (Table 1). 


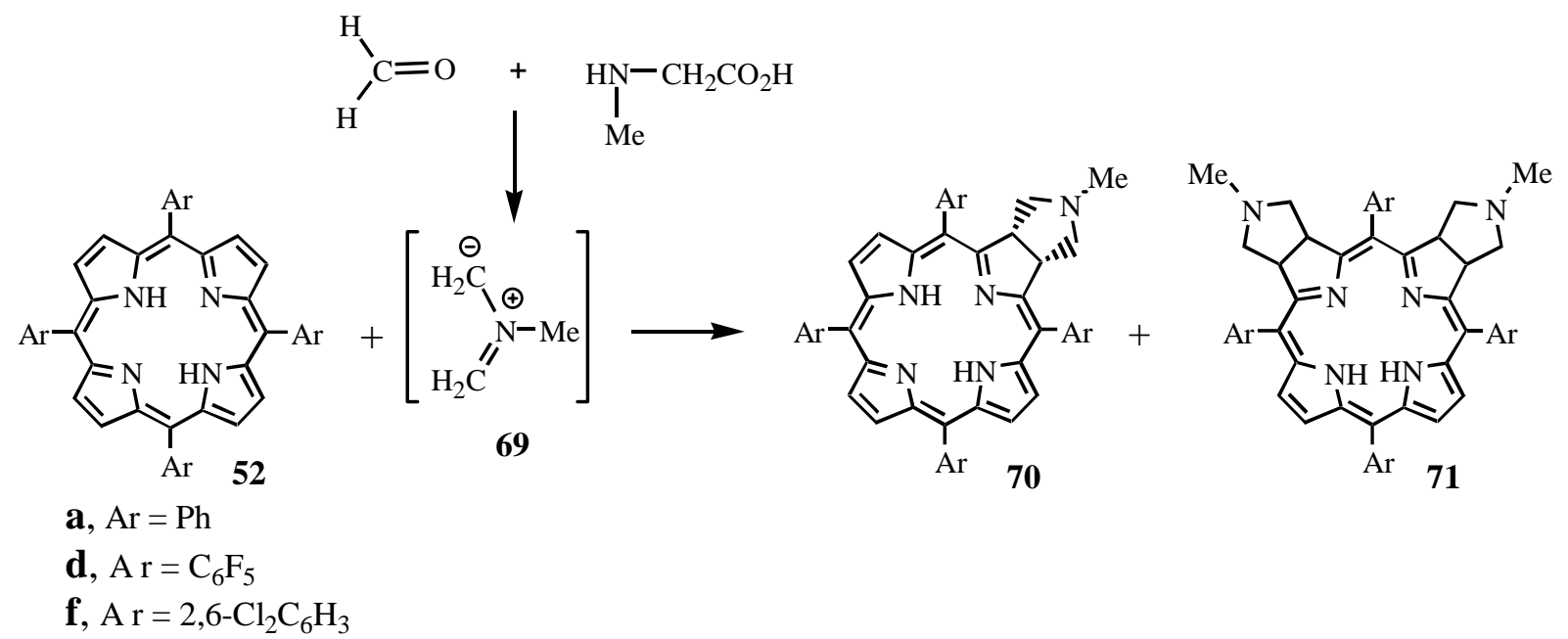

\section{Scheme 16}

Table 1. Product yields of meso-tetraarylporphyrins with azomethine ylide $\mathbf{6 9}^{38}$

\begin{tabular}{ccc} 
meso-aryl group & monoadduct (\%) & bis-adducts (\%) \\
\hline $\mathrm{Ph}$ & 12 & not observed \\
$\mathrm{C}_{6} \mathrm{~F}_{5}$ & 61 & 11 \\
$2,6-\mathrm{Cl}_{2} \mathrm{C}_{6} \mathrm{H}_{3}$ & 26 & 6 \\
\hline
\end{tabular}

Other aminoacids can be used successfully as precursors of different azomethine ylides. As an example, the diasterioisomeric chlorins 72 (35\%) and 73 (30\%) are obtained from the reaction of porphyrin 52d with the 1,3-dipole generated in situ from proline and paraformaldehyde. ${ }^{39} \mathrm{~N}$ Unsubstituted amino acids can also be used. The reaction of porphyrin 52d with glycine and paraformaldehyde in refluxing toluene gives the expected chlorin 74 (47\%) and the isobacteriochlorin (less than $1 \%$ ). ${ }^{39}$
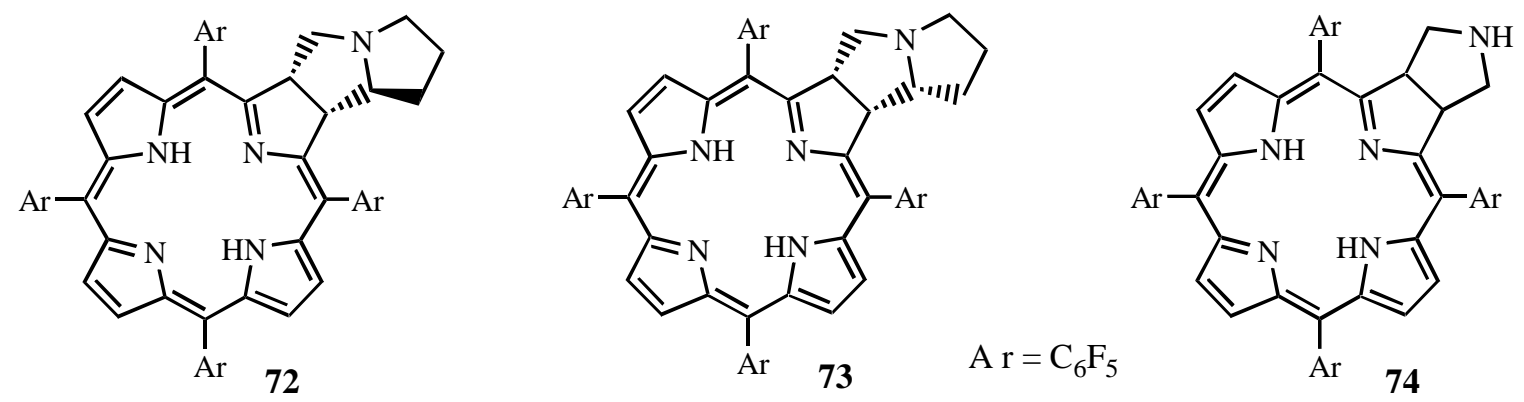

The reaction of porphyrins with nitrones also gives the expected monoadducts and, in some cases, bis-adducts of the bacteriochlorin type can also be isolated and characterized. As an example, meso-tetrakis(pentafluorophenyl)porphyrin reacts with nitrone $\mathbf{7 5}$ (generated in situ) to give the isoxazolidine-fused chlorin 76 (Scheme 17) in 72\% yield (based on consumed starting 
porphyrin). ${ }^{39,40}$ Similarly, chlorin derivatives 78a-d (Scheme 17) are obtained in moderate to good yields from the reaction of same porphyrin with the sugar nitrones $\mathbf{7 7 a - d}{ }^{41}$

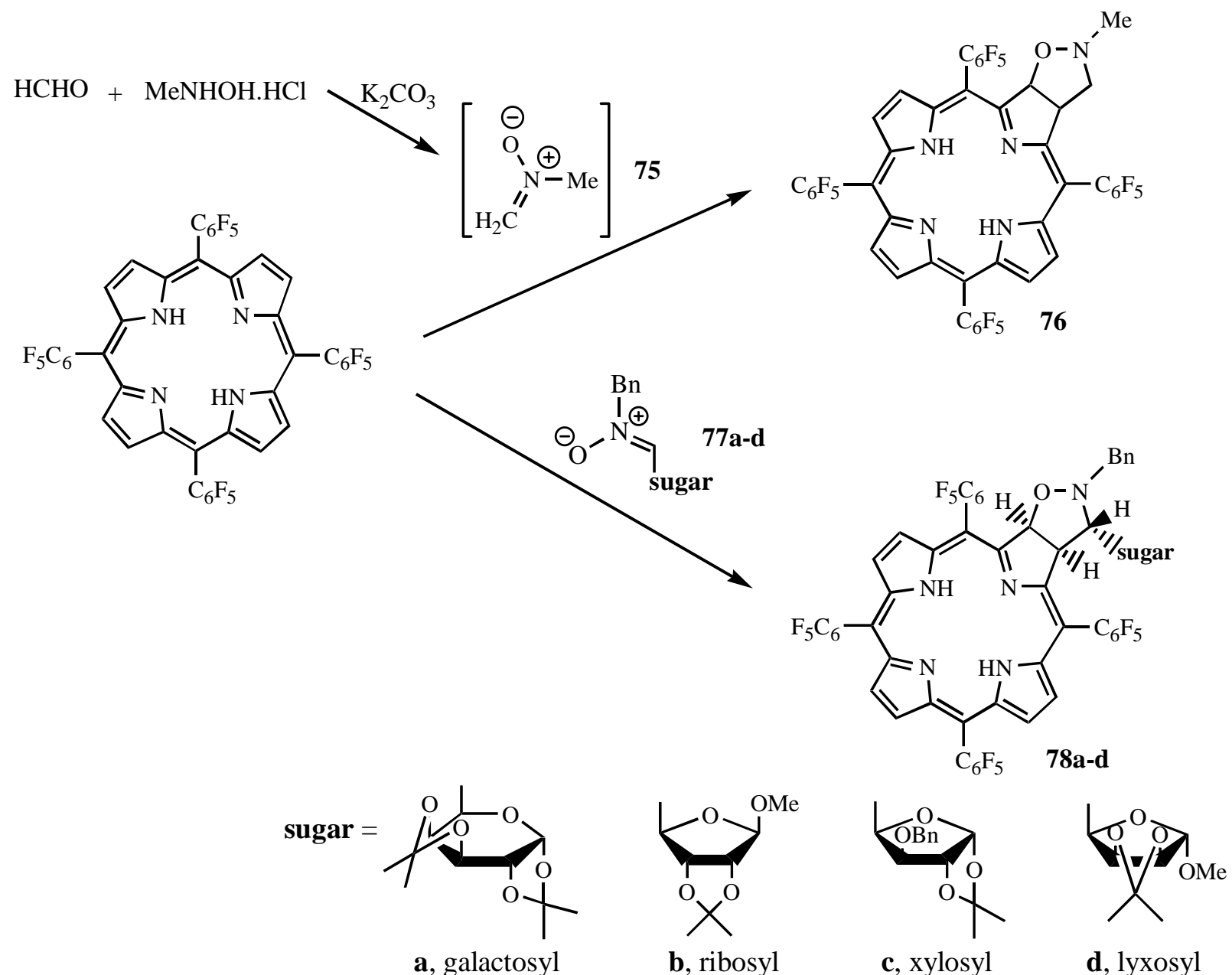

\section{Scheme 17}

Porphyrins react with diazomethane to yield pyrazoline-fused chlorins. For instance, $\beta$-nitromeso-tetraphenylporphyrin $\mathbf{7 9}$ reacts with diazomethane, at room temperature, to afford the pyrazoline-fused chlorin 80 (41\% yield) as the main product. ${ }^{42}$ The pyrazole-fused porphyrin 81 (7\% yield) and the methanochlorin 82 (3\% yield) are also isolated from the reaction mixture (Scheme 18). The pyrazoline $\mathbf{8 0}$ is the precursor of these two minor products: it can be converted easily into $\mathbf{8 1}$ by elimination of nitrous acid with DBU or into 82 by thermal extrusion of $\mathrm{N}_{2}$ in refluxing toluene. 

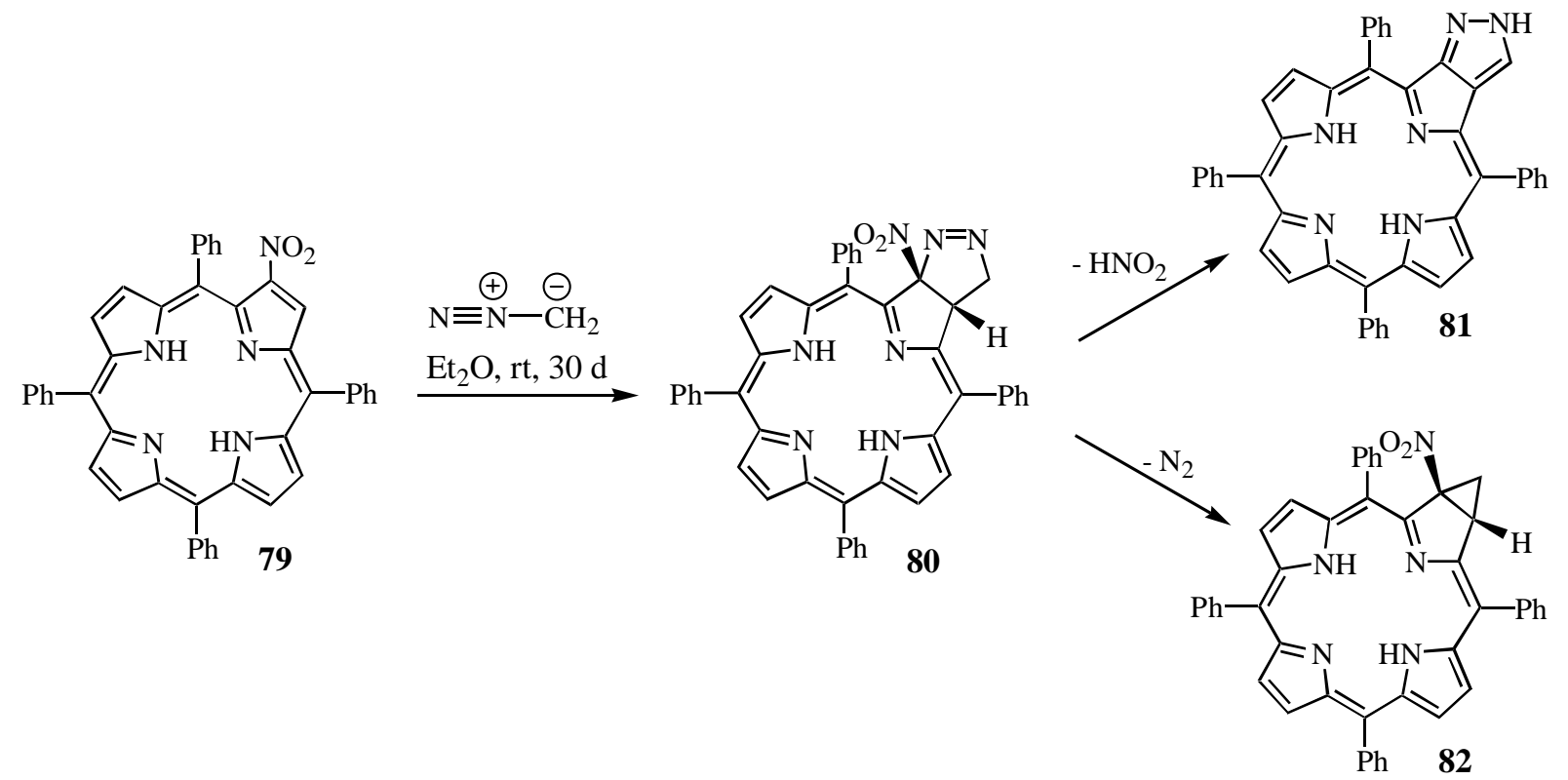

\section{Scheme 18}

Quite similar results are obtained from the reaction of diazomethane with mesotetrakis(pentafluorophenyl)porphyrin (Scheme 19). ${ }^{43}$ Both thermal (refluxing mesitylene) or photochemical extrusion of $\mathrm{N}_{2}$ from the pyrazoline derivative $\mathbf{8 3}$ gives the methanochlorin $\mathbf{8 4}$ in almost quantitative yield.
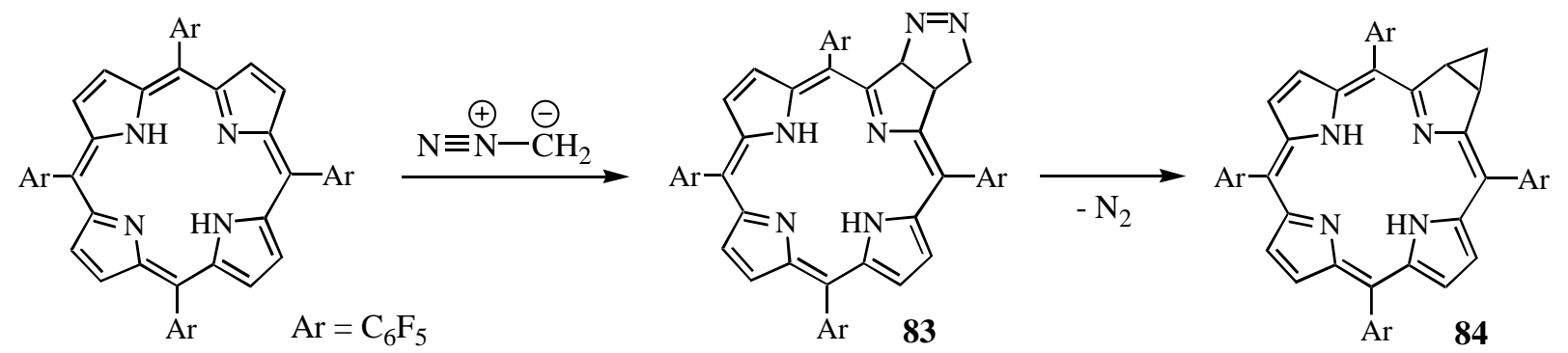

\section{Scheme 19}

Meso-tetrakis(pentafluorophenyl)porphyrin reacts with carbonyl ylides $\mathbf{8 5}$ and $\mathbf{8 7}$ to afford the corresponding [3+2] tetrahydrofuran adducts in moderate yields (Scheme 20). ${ }^{44}$ 

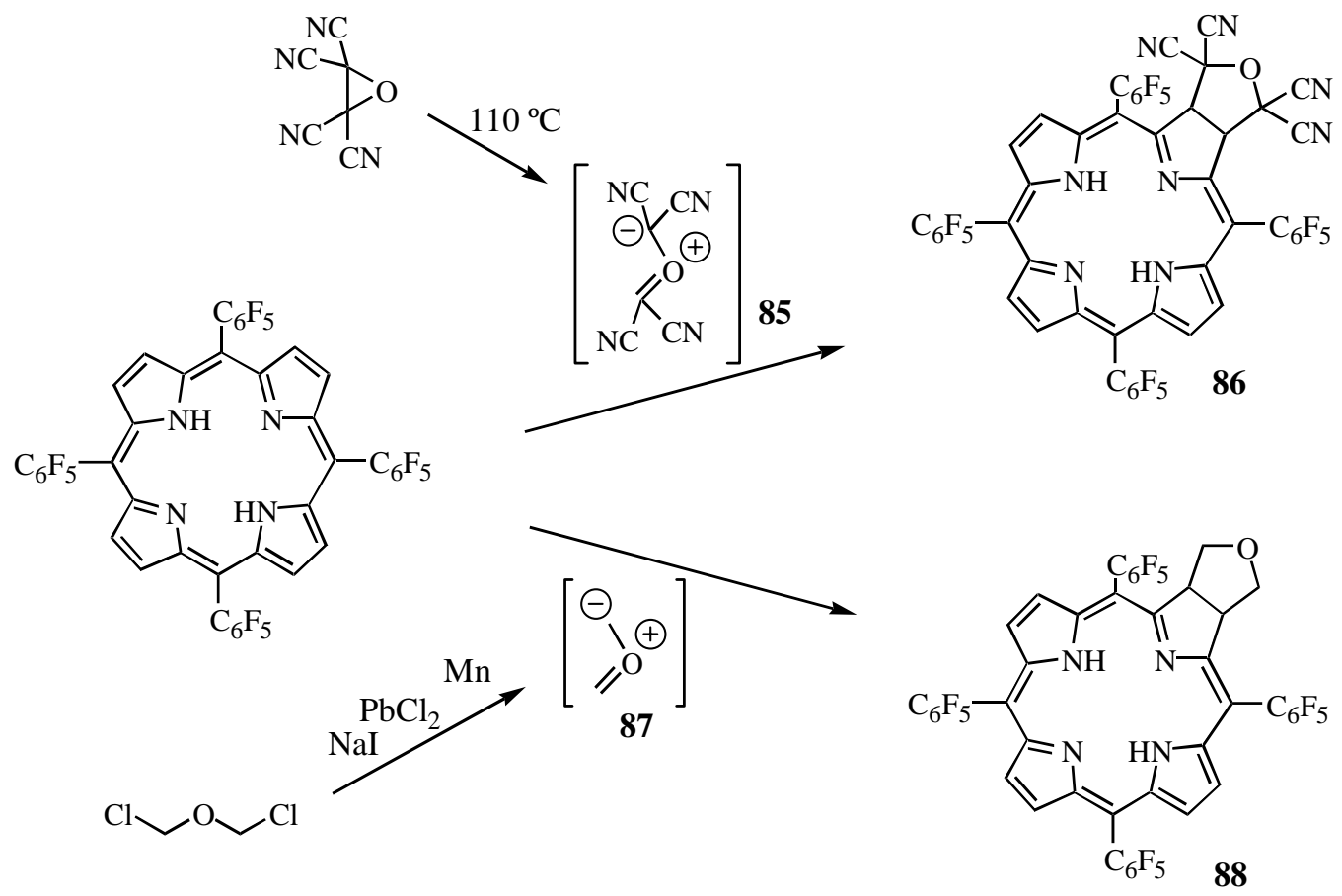

\section{Scheme 20}

\section{Porphyrins as 1,3-Dipoles}

The porphyrinic azomethine ylide $\mathbf{8 9}$ (generated by the reaction of $\beta$-formyl-mesotetraphenylporphyrin, or its $\mathrm{Ni}$ complex, with $N$-methylglycine) reacts with a range of dipolarophiles to yield the corresponding adducts $\mathbf{9 0}$ (or their dehydrogenated derivatives) in good yields (Scheme 21). ${ }^{45,46}$

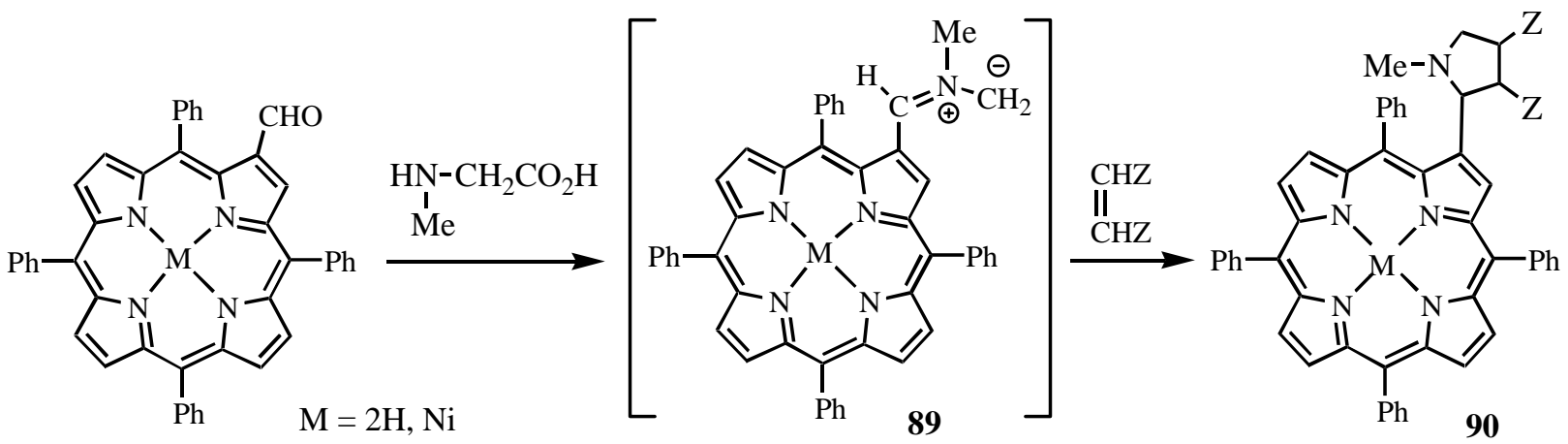

\section{Scheme 21}

Several phytochlorin-fullerene dyads, $\mathbf{9 2}{ }^{47}$ and $\mathbf{9 4},{ }^{48}$ for instance, were prepared by the same procedure (Scheme 22). 


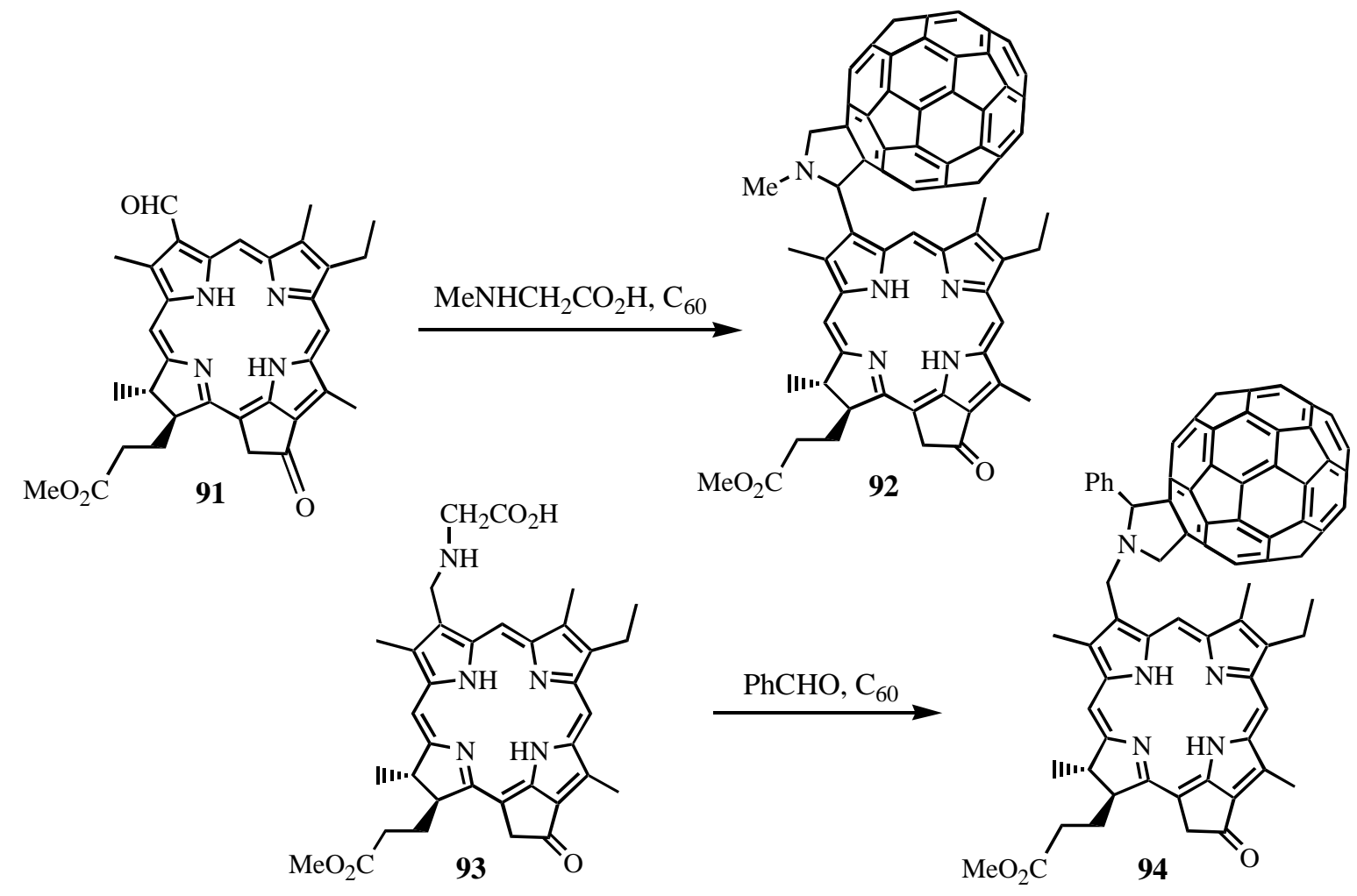

Scheme 22

\section{Electrocyclizations}

When generated in the absence of a dipolarophile, the porphyrinic azomethine ylides $\mathbf{8 9}$ give 1,5electrocyclic ring closure reactions to furnish pyrrolo[3,4-b]porphyrins 95 (Scheme 23). ${ }^{49}$ Similar reactions with $\beta, \beta$ '-diformyl derivatives of meso-tetraphenylporphyrin afford dipyrrolo[3,4-b:3,4-g]porphyrins $\mathbf{9 7}$ or dipyrrolo[3,4-b:3,4-l]porphyrins 99 depending on the relative positions of the two formyl groups (Schemes 24). ${ }^{49}$

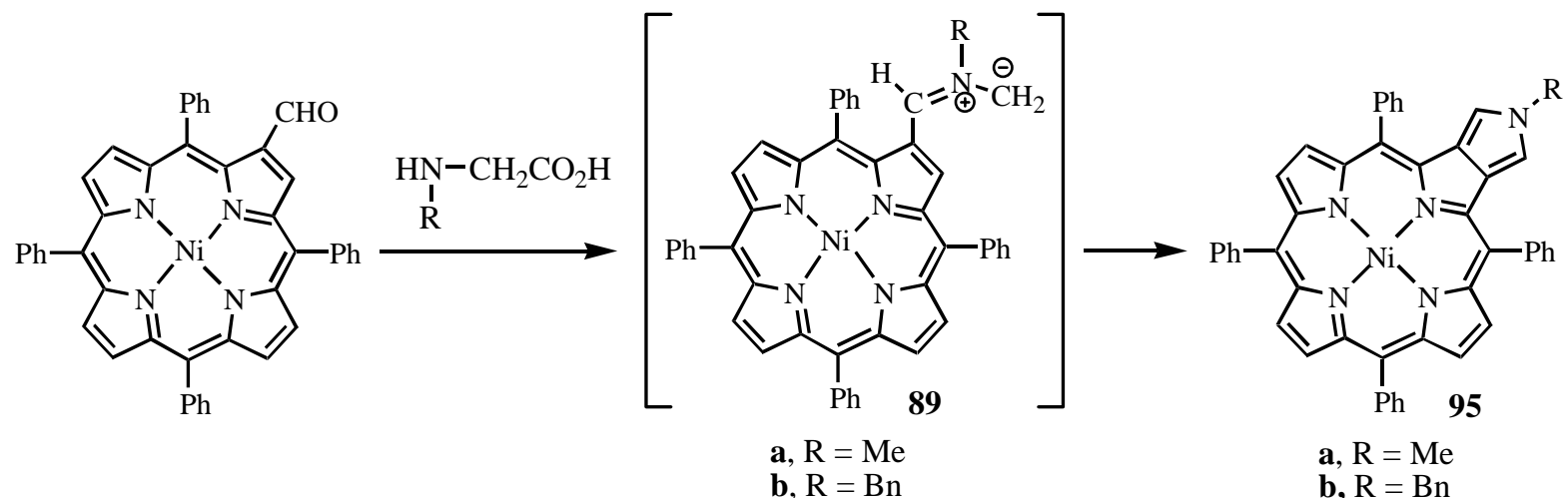

Scheme 23 


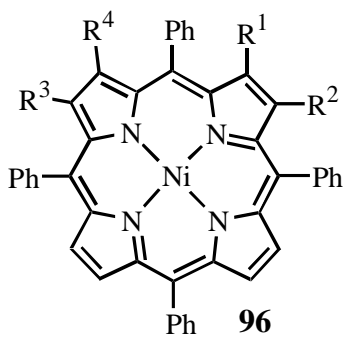

a, $\mathrm{R}^{1}=\mathrm{R}^{3}=\mathrm{CHO}, \mathrm{R}^{2}=\mathrm{R}^{4}=\mathrm{H}$

b, $\mathrm{R}^{1}=\mathrm{R}^{4}=\mathrm{CHO}, \mathrm{R}^{2}=\mathrm{R}^{3}=\mathrm{H}$

c, $\mathrm{R}^{2}=\mathrm{R}^{3}=\mathrm{CHO}, \mathrm{R}^{1}=\mathrm{R}^{4}=\mathrm{H}$

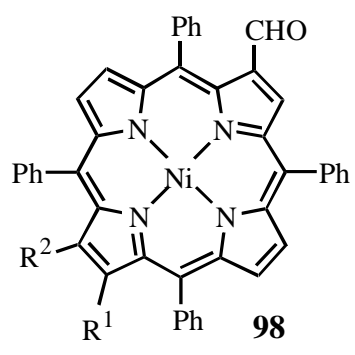

d, $\mathrm{R}^{1}=\mathrm{CHO}, \mathrm{R}^{2}=\mathrm{H}$

e, $\mathrm{R}^{1}=\mathrm{H}, \mathrm{R}^{2}=\mathrm{CHO}$

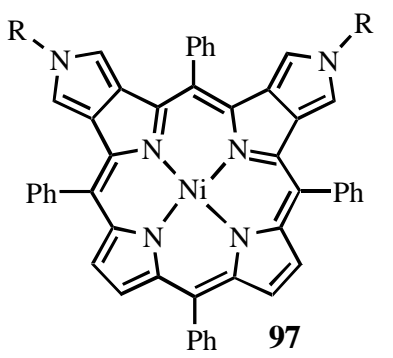

a, $\mathrm{R}=\mathrm{Me}$

b, $\mathrm{R}=\mathrm{Bn}$

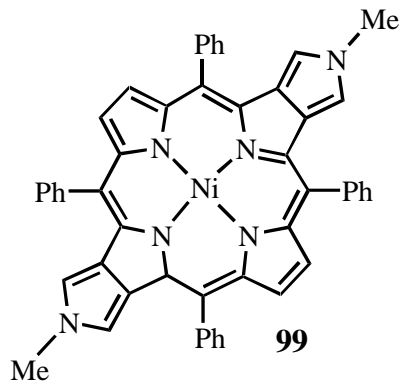

\section{Scheme 24}

\section{Cheletropic Reactions}

Meso-tetraphenylporphyrin ( $\mathrm{Zn}$ complex $)^{50}$ and octaethylporphyrin $(\mathrm{Cu} \text { complex })^{9 \mathrm{~b}}$ react with carbenes to yield methanochlorins and, in one case, bacteriochlorins. For instance, mesotetraphenylporphyrin (Zn complex) reacts with the carbenes generated in situ by coppercatalyzed decomposition of diazomethane, methyl diazoacetate and dimethyl diazomalonate to give the methanochlorins 100a-c. With methyl diazoacetate the bacteriochlorin $\mathbf{1 0 1}$ is also formed (Scheme 25).
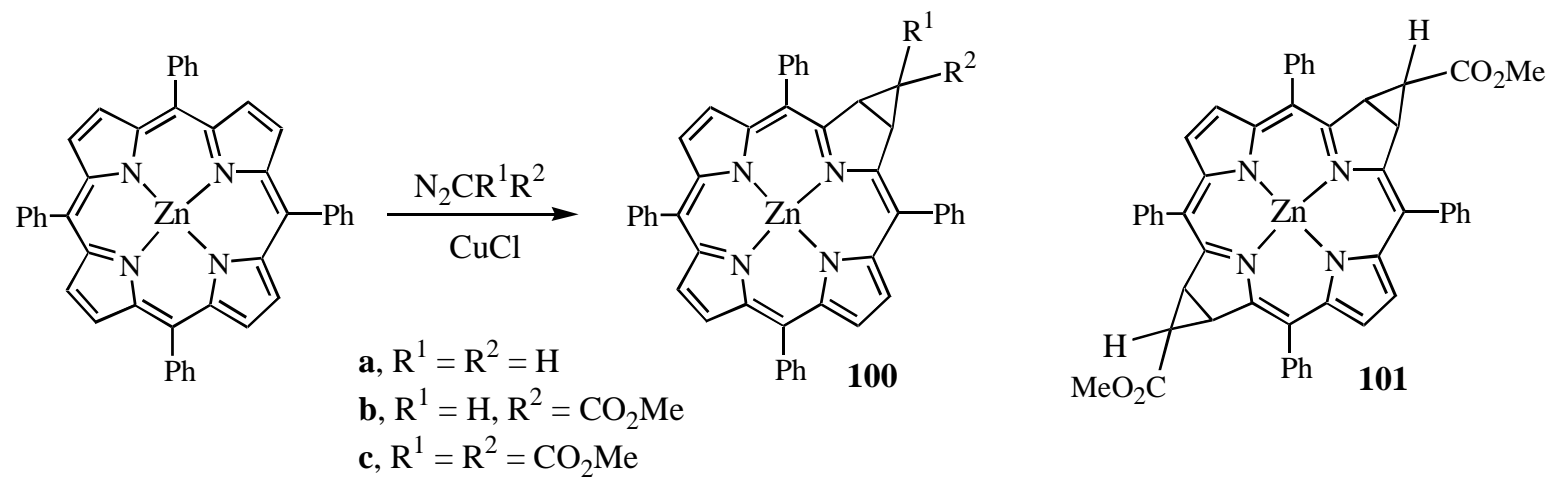

Scheme 25 
The reaction of porphyrins with nitrenes follows a different mechanism than the one with carbenes. Addition of ethoxycarbonylnitrene to octaethylporphyrin yields the ring-expanded meso-homoazaporphyrin 102, resulting from attack at a meso-double bond. Heating this derivative in the solid state or in solution causes ring contraction to the mesoethoxycarbonylaminoporphyrin 103 (Scheme 26). ${ }^{51}$ Ring contraction of $\mathbf{1 0 2}$ to the metal complex of 103 occurs rapidly, at room temperature, in the presence of copper or zinc acetate. The reaction of the $\mathrm{Cu}$ or $\mathrm{Zn}$ complexes of octaethylporphyrin with ethoxycarbonylnitrene gives the corresponding metal complex of $\mathbf{1 0 3}$ directly.

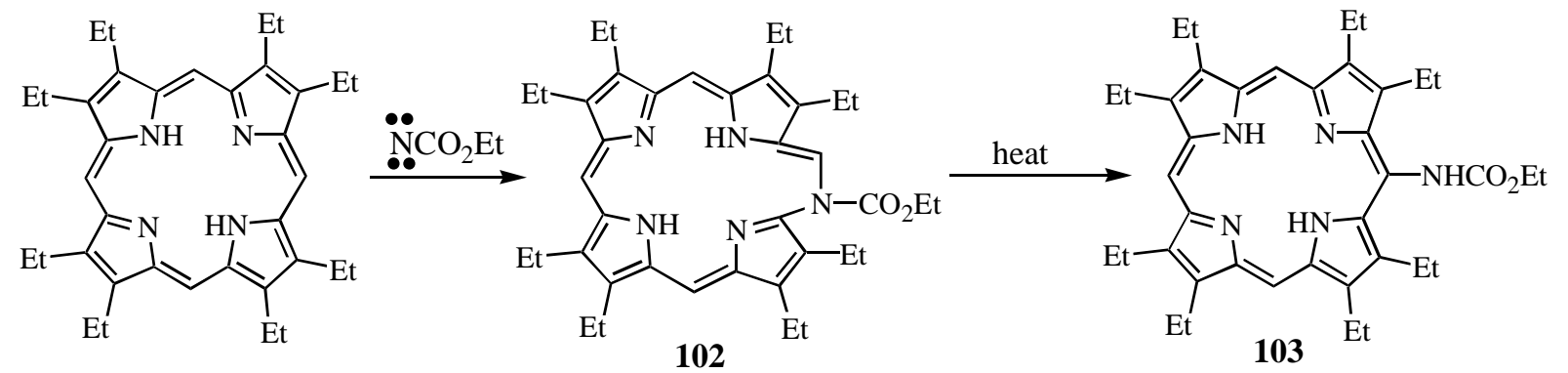

Scheme 26

\section{Acknowledgements}

Thanks are due to the University of Aveiro and to the Fundação para a Ciência e a Tecnologia for funding.

\section{References}

1. Hoppe-Seyler, F. Z. Physiol. Chem. 1880, 4, 193.

2. Fischer, H.; Zeile, K. Liebigs Ann. Chem. 1929, 468, 98.

3. Woodward, R. B. et al., J. Am. Chem. Soc. 1960, 82, 3800.

4. Dolphin D., Ed. The Porphyrins; Vols. I, II, III, IV, V, VI A, B, Academic Press, 1979.

5. Kadish, K. M.; Smith, K. M.; Guilard, R. Eds. The Porphyrin Handbook; Academic Press: San Diego, 2000, Vols. 1-10 and 2003, 11-20.

6. Metalloporphyins in Catalytical Oxidations, Sheldon, R. A., Ed.; Marcel Dekker, 1994.

7. Chemical Aspects of Photodynamic Therapy, Bonnett, R., Gordon and Breach, 2000.

8. Cavaleiro, J. A. S.; Jori, G.; Neves, M.G. P. M. S.; Tomé, A. C.; Tomé, J. P. C.; Valdeira, M. L.; submitted for publication.

9. (a) Grigg, R.; Johnson, A. W.; Sweeney, A. J. Chem. Soc., Chem. Commun. 1968, 697. (b) Callot, H. J.; Johnson, A. W.; Sweeney, A. J. Chem. Soc., Perkin Trans. 1 1973, 1424. 
10. Inhoffen, H. H.; Brockmann, H.; Bliesener, K.-M. Ann. Chem. 1969, 730, 173.

11. DiNello, R. K.; Dolphin, D. J. Org. Chem. 1980, 45, 5196.

12. (a) Morgan, A. R.; Pangka, V. S.; Dolphin, D. J. Chem. Soc., Chem. Commun. 1984, 1047.

(b) Pangka, V. S.; Morgan, A. R.; Dolphin, A. J. Org. Chem. 1986, 51, 1094.

13. Yon-Hin, P.; Wijesekera, T. P.; Dolphin, D. Tetrahedron Lett. 1989, 30, 6135.

14. Faustino, M. A. F.; Neves, M. G. P. M. S.; Vicente, M. G. H.; Silva, A. M. S.; Cavaleiro, J. A. S. Tetrahedron Lett. 1996, 37, 3569.

15. Faustino, M. A. F.; Neves, M. G. P. M. S.; Silva, A. M. S.; Cavaleiro, J. A. S. Chimia 1997, $51,472$.

16. Matsumoto, K.; Kimura, S.; Morishita, T.; Misumi, Y.; Hayashi, N. Synlett 2000, 233.

17. (a) Ma, L.; Dolphin, D. Can. J. Chem. 1997, 75, 262. (b) Zeng, G.; Kozyrev, A. N.; Dougherty, T. J.; Smith, K. M.; Pandey, R. Chem. Lett. 1996, 1119. (c) Vicente, M. G. H. In The Porphyrin Handbook, Kadish, K. M.; Smith, K. M.; Guilard, R., Eds., vol. 1, p 49; Academic Press: San Diego, 2000.

18. Kai, S.; Suzuki, M. Tetrahedron Lett. 1996, 37, 5931.

19. Cavaleiro, J. A. S.; Jackson, A. H.; Neves, M. G. P. M. S.; Rao, K. R. N. J. Chem. Soc., Chem. Commun. 1985, 776.

20. Morgan, A. R.; Kohli, D. H. Tetrahedron Lett. 1995, 36, 7603.

21. Alonso, C. M.; Neves, M. G. P. M. S.; Tomé, A. C.; Silva, A. M. S.; Cavaleiro, J. A. S. Tetrahedron Lett. 2001, 42, 8307.

22. Gunter, M. J.; Tang, H.; Warrener, R. N. Chem. Commun. 1999, 803.

23. Gunter, M. J.; Tang, H.; Warrener, R. N. J. Porphyrins Phthalocyanines 2002, 6, 673.

24. Knapp, S.; Vasudevan, J.; Emge, T. J.; Arison, B. H.; Potenza, J. A.; Schugar, H. J. Angew. Chem., Int. Ed. 1998, 37, 2368.

25. Vicente, M. G. H.; Jaquinod, L.; Khoury, R. G.; Madrona, A. Y.; Smith, K. M. Tetrahedron Lett. 1999, 40, 8763.

26. Liddell, P. A.; Demanche, L. J.; Li, S.; Macpherson, A. N.; Nieman, R. A.; Moore, A. L.; Moore, T. A.; Gust, D. Tetrahedron Lett. 1994, 35, 995.

27. Liddell, P. A.; Sumida, J. P.; MacPherson, A. N.; Noss, L.; Seely, G. R.; Clark, K. N.; Moore, A. L.; Moore, T. A.; Gust, D. Photochem. Photobiol. 1994, 60, 537.

28. Alonso, C. M.; Neves, M. G. P. M. S.; Tomé, A. C.; Silva, A. M. S.; Cavaleiro, J. A. S. Tetrahedron Lett. 2000, 41, 5679.

29. Zheng, G.; Dougherty, T. J.; Pandey, R. K. Chem. Commun. 1999, 2469.

30. Ranasinghe, M. G.; Oliver, A. M.; Rothenfluh, D. F.; Salek, A.; Paddon-Row, M. N. Tetrahedron Lett. 1996, 37, 4797.

31. Tomé, A. C.; Lacerda, P. S. S.; Neves, M. G. P. M. S.; Cavaleiro, J. A. S. Chem. Commun. 1997, 1199.

32. Lacerda, P. S. S. M. Sc. Thesis, University of Aveiro, 1998.

33. Zhao, S.; Tomé, A. C.; Neves, M. G. P. M. S.; Cavaleiro, J. A. S. unpublished results. 
34. Vicente, M. G. H., Cancilla, M. T.; Lebrilla, C. B., Smith, K. M. Chem. Commun. 1998, 2355.

35. Xiao, Z.; Patrick, B. O.; Dolphin, D., Chem. Commun. 2002, 1816.

36. Silva, A. M. G.; Tomé, A. C.; Neves, M. G. P. M. S.; Cavaleiro, J. A. S. Tetrahedron Lett. 2000, 41, 3065.

37. Makarova, E. A.; Korolyova, G. V.; Tok, O. L.; Lukyanets, E. A. J. Porphyrin Phthalocyanines 2000, 4, 525.

38. Silva, A. M. G.; Tomé, A. C.; Neves, M. G. P. M. S.; Silva, A. M. S.; Cavaleiro, J. A. S. Chem. Commun. 1999, 1767.

39. Silva, A. M. G. PhD Thesis, University of Aveiro, 2002.

40. Silva, A. M. G.; Tomé, A. C.; Neves, M. G. P. M. S.; Silva, A. M. S.; Cavaleiro, J. A. S. First Internat. Conference on Porphyrins and Phthalocyanines, Poster 563, Dijon, 2000

41. Silva, A. M. G.; Tomé, A. C.; Neves, M. G. P. M. S.; Silva, A. M. S.; Cavaleiro, J. A. S.; Perrone, D.; Dondoni, A. Tetrahedron Lett. 2002, 43, 603.

42. Silva, A. M. G.; Tomé, A. C.; Neves, M. G. P. M. S.; Cavaleiro, J. A. S. Synlett 2002, 1155.

43. Desjardins, A.; Flemming, J.; Sternberg, E. D.; Dolphin, D., Chem. Commun. 2002, 2622.

44. Flemming, J.; Dolphin, D. Tetrahedron Lett. 2002, 43, 7281.

45. Drovetskaya, T.; Reed, C. A.; Boyd, P. Tetrahedron Lett. 1995, 36, 7971.

46. Silva, A. M. G.; Tomé, A. C.; Neves, M. G. P. M. S.; Silva, A. M. S.; Cavaleiro, J. A. S. J. Org. Chem. 2002, 67, 726.

47. Heleja, J.; Tauber, A. Y.; Abel, Y.; Tkachenko, N. V., Lemmetyinen, H., Kilpeläinem, I; Hynninen, P. H. J. Chem. Soc., Perkin Trans. 1 1999, 2403.

48. Efimov, A.; Tkatchenko, N. V.; Vainiotalo, P.; Lemmetyinen, H. J. Porphyrins Phthalocyanines 2001, 5, 835.

49. Silva, A. M. G.; Faustino, M. A. F.; Tomé, A. C.; Neves, M. G. P. M. S.; Silva, A. M. S.;

Cavaleiro, J. A. S. J. Chem. Soc., Perkin Trans. 1 2001, 2752.

50. Callot, H. J. Tetrahedron Lett. 1972, 1011.

51. Grigg, R. J. Chem. Soc. C 1971, 3664. 